\title{
“There's No One as Irish as Barack O'Bama": The Policy and Politics of American Multiracialism
}

\section{Citation}

Hochschild, Jennifer L., and Vesla Mae Weaver. 2010. “There's no one as Irish as Barack O'Bama": The policy and politics of American multiracialism. Perspectives on Politics 8(3): 737-759.

\section{Published Version}

doi:10.1017/S1537592710002057

\section{Permanent link}

http://nrs.harvard.edu/urn-3:HUL.InstRepos:8944744

\section{Terms of Use}

This article was downloaded from Harvard University's DASH repository, and is made available under the terms and conditions applicable to Open Access Policy Articles, as set forth at http:// nrs.harvard.edu/urn-3:HUL.InstRepos:dash.current.terms-of-use\#OAP

\section{Share Your Story}

The Harvard community has made this article openly available.

Please share how this access benefits you. Submit a story.

\section{Accessibility}




\title{
Author Final Copy \\ "There's No One as Irish as Barack O'Bama": The Policy and Politics of American Multiracialism
}

\author{
Jennifer Hochschild \\ Harvard University \\ Hochschild@gov.harvard.edu \\ Vesla M. Weaver \\ University of Virginia \\ vmweaver@virginia.edu
}

\begin{abstract}
Acknowledgements: Our thanks to Andrew Benitez, Richard Coffin, Tiffany Jones, Daniel Koh, Jay Lundy, and Brenna Powell for their excellent research assistance. Thanks also to Traci Burch, our coauthor of the larger project of which this article is a part, for managing the coding of Congressional hearings and general all-round contributions to developing this argument. Audiences and seminar participants at City University of London, Harvard University, Princeton University, University of California at Berkeley, and University of Manchester made contributions that deepened and clarified our analyses. Finally, we are grateful to C. Anthony Broh, Suzann Evinger, Reynolds Farley, Michael Fortner, Jacob Hacker, David Hollinger, Jeffrey Isaac, Kenneth Prewitt, Lydia Saad, Katherine Wallman, Kim Williams, and several anonymous reviewers for very helpful comments on earlier drafts or in response to queries. Please direct correspondence to Jennifer Hochschild.
\end{abstract}

\begin{abstract}
For the first time in American history, the United States' 2000 census allowed individuals to choose more than one race. That new policy sets up our exploration of whether and how multiracialism is entering Americans' understanding and practice of race. By analyzing briefly earlier cases of racial construction, we uncover three factors important to understanding if and how intensely a feedback effect for racial classification will be generated. Using this framework, we find that multiracialism has been institutionalized in the federal government, and is moving toward institutionalization in the private sector and other governmental units. In addition, the small proportion of Americans who now define themselves as multiracial is growing absolutely and relatively, and evidence suggests a continued rise. Increasing multiracial identification is made more likely by racial mixture's growing prominence in American society demographically, culturally, economically, and psychologically. However, the politics side of the feedback loop is complicated by the fact that identification is not identity. Traditional racial or ethnic loyalties and understandings remain strong, including among potential multiracial identifiers. Therefore, if mixed race identification is to evolve into a multiracial identity, it may not be at the expense of existing group consciousness. Instead, we expect mixed race identity to be contextual, fluid, and additive, so that it can be layered onto rather than substituted for traditional monoracial commitments. If the multiracial movement successfully challenges the longstanding understanding and practice of "one drop of blood" racial groups, it has the potential to change much of the politics and policy of American race relations.
\end{abstract}


O’Leary, O'Riley, O'Hare, and O'Hara

There's no one as Irish as Barack O'Bama.

His mam's daddy's grandaddy was one Fulmuth Kearney

He's as Irish as any from the lakes of Killarney

His mam's from a long line of great Irish mamas;

There's no one as Irish as Barack O'Bama.

--Hardy Drew and the Nancy Boys

It is possible that, by 2050, today's racial and ethnic categories will no longer be in use.

--Migration News ${ }^{1}$

The Hart-Celler Immigration Act of 1965 that removed immigration restrictions based on national origin, and the 1967 Supreme Court decision in Loving v. Virginia that struck down laws forbidding interracial marriage, jointly facilitated powerful demographic changes in the United States. Immigration rose, to over a million people a year in some years. Interracial and interethnic marriages occurred much more often than before; the number and proportion of mixed race children grew; and multiple ways of recognizing group mixture arose in the society, culture, and economy. These changes were politicized in the 1990s by advocacy groups seeking official recognition of mixed race ancestry and identity, and at the same time federal agencies studied new classification systems for counting and analyzing the rapidly changing American population. By 2000, eight states and the federal government recognized self-identified racial mixture for the first time in American history, and almost seven million respondents chose more than one race in the 2000 census ( 823 chose all six possibilities). ${ }^{2}$ Multiracial advocacy organizations celebrated the beginning of a new era.

Recognition of multiracialism received its biggest subsequent boost, of course, in the person of Barack Obama. His White American mother was descended from a wig-maker who left Moneygall, Ireland, in 1850 -- thereby making possible the song, "There's no one as Irish as Barack O'Bama," which has been downloaded from YouTube by millions around the world. The irony of the song, as any sentient person knows, is that Obama's father was a Black Kenyan and Obama grew up as almost but not quite African American.

Is Obama the wave of the future? As the song puts it, is it the case that "From Fenian to Kenyan, it's the American way?" More soberly, how does multiracialism relate to the United States' commonly accepted sharp distinctions among a few races and ethnicities? Various answers are possible. At one extreme, multiracialism will dissolve extant groups into one grand cosmopolitan melange, as in the O'Bama song or José Vasconcelos' concept of the "cosmic race." 3 Alternatively, multiracial advocates and their famous representative are an anomaly in the deeply entrenched, and sometimes cherished, American racial classification system. After all, only a few percent of Americans call themselves multiracial regardless of their ancestry; Obama may be as unusual in his identity as he is in his political skills. Or, multiracialism will contribute to changing, but not dissolving, the ways in which Americans understand, identify with, and practice race. In that view, people will come to understand the concept of race differently, so that they can layer a multiracial identity into a racial identity, rather than thinking of racial identity as fixed, knowable, and singular. 
This article analyzes the development of multiracialism in the United States, and its relationship to the recent history and current politics of the American racial order. Migration News'startling prediction in the second epigraph suggests what is at stake: increasing recognition of mixture and more people identifying as mixed could together signal as well as promote a major change in how Americans understand, identify with, and practice race and ethnicity. ${ }^{4}$ For most of the twentieth century, Americans' racial understandings and practices rested on assumptions that racial groups are mutually distinct, that there are only a few races, and that a person is a member of and identifies with only one race. Political and policy disputes revolved around the appropriate relationship among the few exhaustive and mutually exclusive races, focusing especially on the degree to which racial hierarchy could be justified or how it should be dismantled.

But multiracialism challenges that set of assumptions. Viewed optimistically, it could provide a bridge between previously isolated categories. If "we" and "they" are linked in our own bodies or those of our children or friends, it might be harder (though not impossible, as we know from the antebellum South or the history of most Latin American nations) for one group to separate from and dominate the other. As Herbert Gans puts it, "Most likely, ... the larger the number of multiracials and of multiracial variations, the more difficult it will be for non-Blacks to define and enforce racial boundaries, or to figure out which of the many darker-skinned varieties of multiracials had Black ancestors. In that case, an eventual end of racial discrimination is possible." 5 Such, at any rate, is the hope of advocates of multiracial recognition and identity as well as of optimistic interpreters of Barack Obama's presidential victory.

Looked at pessimistically, an increase in multiracial recognition and identity may dangerously challenge group loyalties that remain essential in a polity where races and ethnicities are still arrayed hierarchically. Multiracialism may even reinforce hierarchy by permitting some non-Anglos to distance themselves from disfavored minority groups -- "a whole host of light-skinned black Americans running for the door the minute they have another choice," in the words of Arthur Fletcher, then chair of the U.S. Civil Rights Commission. ${ }^{6}$ If multiracials have higher socioeconomic status than do monoracial non-Whites, as some evidence suggests, they may be preferred in arenas such as affirmative action or electoral politics, thus deepening non-Anglo subordination.

Looked at skeptically, multiracial self-description may remain rare and multiracial identity thin despite official recognition. In that case, the policy of permitting people to select more than one racial designation is best understood as a minor accommodation of a small fraction of the population and a statistical headache for data analysts. It will matter little, politically or theoretically, and the extant American racial and ethnic order will remain largely intact.

It is too early in the history of multiracial classification and identification to tell whether a strong identity will develop and what impact such an identity might have on the American racial order. As we show below, however, potent forces in the polity and society are encouraging Americans to relax the assumptions about race that predominated over the past few generations. The speculation by Migration News seems right; the alternative of reverting to a few discrete nominal categories is becoming more and more unlikely for Americans in the twenty-first century.

We propose to gain leverage on the recent development and possible futures of multiracial identity by bringing together two disparate topics - the trajectories of racial classification schemes in the United States, and the scholarly literature on policy-politics 
feedback. That is, we will briefly show how racial mixture has been discursively, legally, and politically constituted in the United States since the Civil War, and how interactions among policy, politics, institutions, and social dynamics reinforced or undermined those racial constructions. We argue that four factors - demographic change, formal institutionalization, societal dynamics, and the balance between political support and opposition - shape whether feedback processes occur such that a change in classification becomes entrenched over time, or whether the policy fails to generate feedbacks so that a change in classificatory policy does not last. We then use this framework to analyze the many facets of contemporary multiracial identity and identification.

The analysis yields fascinating puzzles, which will keep questions about racial construction and the blurring of categorical boundaries vibrant for years to come. We find that mixed-race categories are being widely institutionalized, that multiracial self-identification is growing and is likely to continue to do so, but that multiracial identity either is weak or is not generating the kind of race-based political organization and mobilization that Americans have become familiar with. The policy, institutions, and social context all point toward a new set of political configurations revolving around mixture -- but the politics are not moving in that direction, at least not yet or not in the ways that we expect them to.

Why not? One possibility is simply that multiracial identity is and will remain too weak or diffuse to compete against established monoracial identities. But another possibility is that multiracialism cannot be understood as adding another group to the American racial order, like Hispanics were added after 1970. Instead, multiracial identity may contradict our usual understanding of racial identity as singular; multiracials might be a group without group boundaries, united mainly by the sense of not being racially unitary. Their identity may be fluid and additive rather than zero-sum and exclusive. ${ }^{7}$ Indeed, as we show later, multiracials' beliefs and attitudes are generally located in the middle of the traditional racial divide. Thus the growth of multiracial self-definition could lead to a softening of racial opinion polarization, or at least create an important middle group that could be a constituency for compromise on racially divisive issues.

The study of multiracialism provides a new angle of vision into a wide array of questions about a racial order. One could compare Americans' treatment of racial mixture with that of other nations. ${ }^{8}$ One could use the framing of a policy-politics feedback loop to evaluate why broad racial orders persist, evolve, or disappear. ${ }^{9}$ One could compare biracialism to other forms of intersectionality in order to probe ways in which race is, and is not, "like" gender, class, or sexuality. ${ }^{10}$ One could weigh the normative value of intense solidarity within a monoracial group against the value of celebrating mixture, hybridity, and impurity. ${ }^{11}$ All of those topics, and more, could be illuminated by studying American multiracialism - but we save them for another day. If we can explicate what is happening in this arena, why, how it relates to earlier ventures in the same direction, and why it matters for the future of American racial dynamics, that will more than suffice for one article.

\section{American Adventures in Racial Construction}

By now a voluminous literature has developed on racial construction in the United States over the past 400 years. ${ }^{12}$ Here we focus on only a small part of it, the creation of racial categories through deliberate governmental policy choices. Classification rules can be an important element of a policy-politics feedback loop since they "play an active role in constructing and positioning ... groups, defining their boundaries and infusing them with political meaning." Sarah Igo's observation about opinion surveys holds also for official data collection: "a society 
[is] changed by the very tools employed to represent it.... The public is simultaneously object, participant, and audience." Even more than a survey, an official census can foster a new politics because "censuses created serial, aggregable, counterposed majorities and minorities, which, starting as formal entities, were positioned in due course to assume political reality" - including to try to change the classification system itself. ${ }^{13}$

As we noted earlier, some official attempts at racial construction endure for decades, while others quickly disappear. Some have a deep impact on group formation and practice, while others remain "merely" classificatory. By looking at two pairings of racial constructions that did, and did not, take hold and deepen over the twentieth century, we can see what factors generate a self-reinforcing policy feedback loop in the arena of a racial order. That will set the stage for looking more closely at the contemporary phenomenon of multiracialism.

The Mexican Race and Hispanic Ethnicity: In 1930, the U.S. census bureau added "Mexican" to the "Color or Race" inquiry, instructing its enumerators that "practically all Mexican laborers are of a racial mixture difficult to classify, though usually well recognized in the localities where they are found. In order to obtain separate figures for this racial group, it has been decided that all persons born in Mexico, or having parents born in Mexico, who are definitely not white, Negro, Indian, Chinese, or Japanese, should be returned as Mexican." When the census was taken, the Mexican government, members of Congress with Mexican American constituents, and advocacy groups vehemently protested on the grounds that all Mexicans were White. ${ }^{14}$ To our knowledge, no one supported this change in the classification system -- especially the potential constituency group that would lose its tenuous hold on White status in an intensely hierarchical racial order. The census bureau retreated, with the director noting wryly that "the classification by race or color of ... populations is not only very difficult, but is a very delicate matter to the United States Government," and decreeing that henceforth "Mexicans are Whites and must be classified as 'White'. This order does not admit of any further discussion, and must be followed to the letter." 15

There the matter rested for three decades; Mexicans were officially White. In 1970, however, the Nixon administration instructed the census bureau to enumerate some Hispanics, as part of the Republican Party's effort to woo a growing group of relatively unattached voters. ${ }^{16}$ The "procedural flow chart" for 1970's enumerators unintentionally demonstrated just how complicated it was to define and find Hispanics:

[Figure 1 about here]

Nevertheless, the category persisted, and remains the lone ethnicity that the authoritative Office of Management and Budget (OMB) permits. ${ }^{17}$

Three factors - demographic change, the balance between political support and opposition, and the degree of institutional support for the new designation -- explain both the rise and fall of "the Mexican race" and the rise and persistence of Hispanic ethnicity in federal classification systems. In a 1928 appropriations hearing, a member of Congress asked the census director "what you did with those Mexicans who came over in swarms?" The response was the Mexican race on the subsequent census. After 1930, protest overrode Congressional pressure and in any case, many Mexicans were repatriated in the 1930s -- so the political and demographic balances shifted in the opposite direction, and the Mexican race disappeared. Since there had been no institutional structure built around the addition of a new racial category on the 1930 census, the new category could be abolished as readily as it was created. 
By 1970, the number of Mexicans "coming over" was again rising. But this time the party in power chose to woo rather than (only) subject them to surveillance. And as a consequence of inclusion in civil rights, affirmative action, and voting rights laws and regulations after decades of de facto segregation and subordination, Hispanics could see benefits to a separate designation that outweighed the costs of losing putative Whiteness. ${ }^{18}$ Some potential supporters of the new policy also appreciated the social and cultural value of a nonWhite identity. Finally, unlike the 1930s, after 1970, Hispanic members of Congress, energetic advocacy groups, census advisory committees, and experts who wanted to keep track of the rising Latino immigration combined to keep Hispanic on the census, despite occasional and rather half-hearted opposition. ${ }^{19}$

Over time, this separate ethnic designation has solidified in everything from classification systems through policy networks, electoral campaigns and candidacies, individuals' identities, and popular culture; it is hard to imagine that the steps down this path will ever reverse or change direction. In short, the feedback loop between invention of Hispanic ethnicity on the census and the politics of Hispanicity began with the impetus of demographic change and grew through institutionalization and the creation of a robust, committed constituency.

Mulattoes and the One-Drop-of-Blood Rule: Starting in 1850, for eighty years the federal government enumerated mulattoes, and occasionally quadroons and octoroons. The rules for defining these groups varied over the years and were never very precise; one typical census instruction to enumerators read

Be particularly careful to distinguish between blacks, mulattoes, quadroons, and octoroons. The word "black" should be used to describe those persons who have threefourths or more black blood; "mulatto," those persons who have from three-eighths to five-eighths black blood; "quadroon," those persons who have one-fourth black blood; and "octoroon," those persons who have one-eighth or any trace of black blood. ${ }^{20}$ The reasons for enumeration remained as murky and inconsistent as the designations of individuals were. ${ }^{21}$ Nevertheless, government officials clearly perceived and attempted to quantify racial mixture. ${ }^{22}$ "Mulatto" lasted on the census through 1920 (except in 1900), after which it disappeared from political, legal, and mainstream media usage.

At the same time that mulattos were being enumerated and their socioeconomic characteristics carefully tabulated, states were developing laws aimed at sharpening and heightening the division between racial groups. Legislators knew that they were constructing racial boundaries; as one careful analyst pointed out in 1910, "it is this gradual sloping off from one race into another which has made it necessary for the law to set artificial lines." 23 It turned out to be frustratingly difficult to do so. For several decades, southern states passed an array of laws broadening the definition of who counted as Negro, adding new groups to the list of people prohibited from marrying or bequeathing property to one another, and deepening penalties for violation of the new laws. ${ }^{24}$ The changes mandated by these sequential laws were not always linear, some were contested, and the timing was inconsistent across states. The 1910 reference book required eight closely-reasoned pages to explain "What is a Negro?", culminating in a diagram, reproduced in figure 2, that was optimistically described as "probably clarify[ing] these definitions." (The book then required another two pages to explain the diagram.)

[Figure 2 about here]

By the mid-1920s, however, states had mostly completed writing laws which subsumed everyone with mixed Black and White ancestry under the category of Negro. ${ }^{25}$ They became 
known as "one drop of blood laws" because they broadened the definition of a Negro to include anyone with one Black ancestor from five generations earlier. The one-drop rule became the reigning understanding of Blackness in the United States for the rest of the twentieth century, locked firmly into place in legal and policy arrangements as well as in social and cultural interactions, individual identities, and political practice. It achieved an almost taken-for-granted quality in Americans' racial practice.

The decline of "mulatto" and the solidification of sharp boundaries between Black and White were not inevitable. Public discourse and public policies had recognized racial mixture for the prior three centuries of American history, and most other countries with both Blacks and Whites continue to officially recognize racial mixture. So why did the one-drop rule attain hegemony in the American racial order? Unlike the case of the Mexican race and Hispanics, demographic change and a shifting political balance between support for and opposition to an innovation do not explain the rise and decline of mulatto and the rise and persistence of the official effort to maintain White purity. The explanation lies in other mechanisms that foster a policy feedback loop - social norms and practices, and institutionalization - as well as in a distinct and unusual form of politics that consisted of incontestable power rather than a changing balance between supporters and opponents.

African Americans were individually and collectively ambivalent about the category of mulatto. Some were proud to claim mixed heritage and some were ashamed of it; some thought that racial boundary blurring would help the Black race overcome hierarchy and oppression while others thought that any move toward boundary blurring would undermine essential group solidarity. ${ }^{26}$ But in terms of policy development and implementation, it did not matter what Blacks thought or wanted; they had no power in the first few decades of the twentieth century to influence any policy decisions. Whites controlled all the policy levers.

Since Whites controlled all policy choices in the racial arena, one must look to their preferences to explain the shift from mulatto to one-drop rules. Mulatto first appeared on the census through an unlikely alliance of northern liberals seeking information about slaves to show that they were people and southern supporters of the theory of polygenesis seeking information about slaves to prove their claim of separate species. It remained on the census through the early twentieth century because a few well-placed White politicians and scholars sought to determine if people with "mixed blood" were indeed physically degenerate and incapable of reproduction. Once census data proved that belief wrong, interest in enumerating and evaluating racially mixed people (Indian/White combinations as well as Black/White combinations) waned.

Conversely, demand for one-drop-of-blood rules grew as southern states broadened and deepened Jim Crow segregation policies in the early 1900s. The logic is simple; one cannot segregate Blacks from Whites, never mind humiliate and endanger them, if the two groups cannot be sharply differentiated. As Whites' preferences for racially segregated hierarchy was institutionalized, other policies and politics followed - creating a tight and robust feedback loop. Southern Black men were disfranchised, so with rare exceptions, White candidates could compete on the grounds of being more enthusiastic about segregation than their rival. The southern economy depended on a poor, immobile, and powerless workforce; mainstream southern media and culture offered virtually no alternative visions. To summarize a long and complex dynamic, one-drop laws directly enabled institutions such as separate schools, hospitals, courts, and transportation systems, and indirectly fostered others that engaged in social interactions, market processes, and electoral politics - all of which depended on and reinforced the bright line between Black and White. Until the powerful disruptions of World War II, the 
Cold War, Black and White resistance, and mass media portrayals of White violence undermined Jim Crow segregation, the feedback loop was robust. Even with the successes of the civil rights era, it took another generation for the separate institutions to (partially) unwind and for the classification system underlying Jim Crow segregation to be challenged.

Thus, in a way that the long-standing classification of racial mixture never did, one-drop rules united compatible social norms, an all-powerful constituency with no serious opposition, and society-wide institutionalization into a tight cluster. This feedback loop was reinforced by Blacks' eventual enthusiastic incorporation of one-drop racial identification as a way to maintain group solidarity and fight racial inequality. That point, of course, leads directly to the politics of multiracialism.

Other systems for classifying people with complex ancestry -- enumerating whites' "mixed parentage" and mother tongues, Indians' fractions of black and white blood, the Asian nationality of "Hindoo" -- came and went during the decades between the Civil War and the Depression. We note them here to remind readers of just how fluid the system of racial categorization has been at some points in American history. But changes in these classificatory policies can be explained by the same factors we used to explain changes in classification of Hispanics and blacks, so we need not detail them here. Demographic change, societal norms and practices, institutionalization, and the political balance between support and opposition for a given policy together provide the mechanisms for understanding the trajectory of a policypolitics feedback loop, at least in the arena of racial construction.

\section{Recognizing Self-Identified Racial Mixture}

By the last half of the twentieth century, Americans had largely forgotten most of this history of robust racial construction and deconstruction. At least since the 1930s, European immigrants of mixed parentage and many mother tongues have been consolidated into Whites; mulattoes, quadroons, octoroons, griffes, and Melungeons had all become Black; half-breeds were Indians; and Hindoos were no more. Hispanics remained ambiguously an ethnicity or a race, but were commonly understood to be not White. The American racial order revolved around an apparently stable, small set of exhaustive and mutually exclusive races; policies were designed and implemented with this set of groups in mind, as were the politics of racial contestation and identity. Americans' disputes about race focused on how hierarchical the racial order should be, not who was in what race or what a race consisted of.

This stable feedback loop started to change in the 1980s, when supporters of the concept of multiracial identity sought governmental recognition of self-defined racial mixture. Many activists identified with one race, but had spouses of a different race and racially mixed children; a few were themselves racially mixed and committed to multiracialism as a stand-alone identity. ${ }^{27}$ After congressional hearings in 1993 and 1997, reports from the National Academy of Sciences and other experts on the United States' demographic change, survey experiments on the likelihood of multiracial identification, analyses by a federal interagency review committee and by the census bureau itself, and adoption of "select one or more" by several states, ${ }^{28}$ the federal government acted.

In 1997, OMB issued the first executive branch ruling on racial data classification since 1977. These Revisions to the Standards for the Classification of Federal Data on Race and Ethnicity changed the definitions of some monoracial categories, distinguished another, and mandated that "when self-identification is used, a method for reporting more than one race should be adopted." While focusing on the 2000 census, the Revisions also stated that "other Federal programs should adopt the standards as soon as possible, but not later than January 1, 
2003, for use in household surveys, administrative forms and records, and other data collections." 29

Census 2000 duly included the instruction, "Mark one or more races to indicate what this person considers himself/herself to be" ${ }^{30}$ in question 8 , "What is Person 1's race?" With that, according to then-census director Kenneth Prewitt, "We turned a corner about how we think about race in this country.",31

\section{Institutional Expansion of the New Policy}

This will make our whole education system look different, and nobody will know whether we are going forward or backward.

The [traditional] racial categories have lost their meaning. --Gary Orfield ---Superintendent Jack Dale of Fairfax County Public Schools ${ }^{32}$

Whether one laments the change, like Orfield, or endorses it as timely and appropriate, like Superintendent Dale, the policy of permitting the report of multiple races has been institutionalized. It first moved deeply into the federal government, and is now moving broadly into American society. Thus one mechanism for a policy-politics feedback loop - and one that is necessary, if not sufficient - is in place.

Government Agencies: In 2001, in accord with OMB's mandate in the Revisions to the Standards and with its routine oversight of proposed federal systems for collecting new data, the Department of Justice began to "include counts of persons who have identified themselves as members of more than one racial category." The Department of Commerce also brought its surveys into compliance, as did the Department of Agriculture and the Federal Reserve Board in 2002. The Department of Health and Human Services followed suit the next year, and the Department of Defense also declared itself "compliant with this OMB reporting guideline."33 Momentum picked up as the decade advanced. In 2005, the Centers for Disease Control and Prevention and Department of Labor required, and the Food and Drug Administration recommended, that funded research include "Multiracial." The Equal Employment Opportunity Commission (EEOC) published a new standard for employers' reports requiring "two or more races" in order to "accommodate... the government-wide Revisions [of 1997]." The National Science Foundation now asks applicants to "select one or more." Most important was the 2007 "Final Guidance on Maintaining, Collecting, and Reporting Racial and Ethnic Data to the U. S. Department of Education.” By 2010-11, all educational institutions must collect information on "whether the respondent is from one or more races" and report the number choosing "two or more races." ${ }^{\text {"34 }}$ In short, the new federal classification policy of permitting more than one racial self-definition has grown strong roots; the undramatic but powerful means was OMB's standard authority to review and approve agencies' proposals for new data collection.

At levels or agencies of government not subject to OMB directives, the pattern of policy change remains mixed. The National Mail Voter Registration Form, valid in almost all states, includes "Multi-racial" but tells users to follow their state's instructions for identifying race or ethnicity. As of 2008, only North Carolina specified "two or more races," although seven others permit more than one choice, sometimes on the federal form only and sometimes on both state and federal forms. 
Most states have been slow to change their classification systems. Even in California, where a quarter of the United States' mixed race population lives, legislators have proposed to no avail the "Ethnic Heritage Respect and Recognition Act," which would require the use of "mark one or more" in state data collection. An expert explained why it has not passed:

The bill would force changes in the way state agencies count and store data--thereby costing money--and it's often very hard to clear bills from the appropriations committees if they have more than insignificant costs. That said, getting out of the appropriations committees is not impossible if there's enough political support... There was very little official opposition to the bill ..., but a certain degree of indifference. ${ }^{35}$

Concern about costs and legislators' need to set priorities are standard features of political calculation; absent a powerful push, the status quo is not changed. OMB provided that push at the federal level, but there is no equivalent agency at the state level. It seems plausible, however, that states will eventually follow the path of the federal government as their own demographics change and as they find it increasingly costly and inefficient to be at odds with federal classification systems.

Private Organizations: Until recently, most private actors also lacked a mandate or incentive to change their practices in this arena, and few did so. But that situation is changing. To comply with the 2007 Department of Education ruling, all educational institutions from prekindergarten through universities will soon permit students to choose more than one race. ${ }^{36}$ High school students taking ACT's Scholastic Test now have the option of "multiracial," and the College Board is experimenting with two SAT formats, both telling the user to "check one or more of the following options that you identify with." As of 2009, the Common Application form used by about 350 American colleges and universities instructs students to "select one or more of the following ethnicities," with five specified groups (as in the census, Hispanic identification is asked separately). In short, institutionalization has moved from federal agencies to organizations with direct mandates to comply with or indirect links to the new classification policy.

Some private enterprises are also responding to the new federal policy. In fall 2009, we examined the application form for entry-level white collar jobs at Fortune Magazine's hundred largest corporations. Fifty permitted applicants to specify two or more races, twenty permitted only one racial response, nineteen did not ask for racial and ethnic data, and we were unable to obtain the relevant information for the final thirteen. As in the educational arena, newly implemented changes in federal agencies' reporting requirements may be inducing at least large employers to make the same change; the Chamber of Commerce endorsed EEOC's 2003 proposal to require reporting the number of employees identifying with two or more races. ${ }^{37}$

In another arena, an increasing number of public opinion surveys or polls have started to permit multiple racial identifications. They include the American National Election Studies, the Washington Post (on some occasions), the National Longitudinal Survey of Adolescent Health, Newsweek surveys in 1995 and 2009, the National Longitudinal Survey of Freshmen (NLSF), the Children of Immigrants Longitudinal Study (CILS), the National Youth Risk Behavior Survey, the Panel Survey of Income Dynamics, the Current Population Survey, the General Social Survey -- and perhaps others. In a recent survey, the American Political Science Association asked respondents, "What is your race or ethnic origin? Check all that apply" (emphasis in original). The Implicit Association Test, downloaded by over three and a half million users, also allows a multiracial designation. If more survey organizations follow these leads, a classification system that includes the option of choosing more than one race may become an analytic, and then empirical, commonplace. 
A key component of a policy-politics feedback loop - institutionalization -- is established in the federal government, and growing in organizations that deal with federal agencies and among researchers. As more public and private actors change their procedures for enumerating race, the cost of retaining earlier classification systems grows and the benefits of following the new policy increase. By following the trajectory of one-drop rules and becoming embedded in laws and their public manifestations, multiracialism could supersede that long-standing classification system.

\section{Social Context and Underlying Trends}

As we saw with one-drop laws and the category of Hispanic, a feedback loop is much more likely to take hold if it accords, respectively, with broad societal trends or major demographic shifts. No political scientist accepts the cliché that demography is destiny, and almost none believe any longer that political disputes merely manifest structural economic conflict.

Nevertheless, all would agree that one is more likely to reach a destination by flowing with a tide than fighting against it. The direction of the tide in this case is clear; the United States is becoming more multiracial in a variety of ways.

Demographic Trajectories: To begin with, literal multiracialism is increasing. Intermarriage is rising sharply; by 2004, almost a fifth of marriages by Black men under age 30 and a tenth of marriages by young Black women were to non-Black spouses. About 20 percent of young Asian Americans, both men and women, married outside their race, as did fully two-thirds of young American Indians. In none of these cases is marriage to Hispanics counted as interracial; if it did, the proportions would be higher. ${ }^{38}$

Trajectory may matter more than absolute numbers in determining a social trend. There is no ambiguity here, with the possible exception of Asian American intermarriage, as figure 3 shows:

[Figure 3 about here]

As the scale on the $\mathrm{Y}$ axes shows, the absolute level of Asian intermarriage remains the highest even though it has declined in recent decades, probably due to the rise in the number of Asian immigrants. ${ }^{39}$ The main point of Figure 3, however, is the clear inflection point in the 1970s, followed by a steep upward slope in intermarriage for two of the three groups. Continued increasing rates of intermarriage seem likely, and a reversal of the trend unlikely, especially since multiracials themselves tend to marry Whites. Furthermore, unlike several decades ago, in all three racial groups the better-educated are now more likely to intermarry. ${ }^{40}$

Interracial relationships are now the norm for young adults in some places; two-thirds of young Californians have dated someone of another race and almost nine out of ten profess willingness to marry across racial lines. ${ }^{41}$ Less than a fifth of adult children of immigrants in New York City think endogamous marriages are important. Between 30 and 56 percent (depending on the interviewees' nationality) of those married or cohabiting have partners outside their group. In this young, urban sample, even three in ten native-born Whites and Blacks have partners outside their own race. "Feelings about intergroup dating sharply differentiated second generation youth from their immigrant parents," but even parents seem to be coming around. ${ }^{42}$ Older adults are themselves moving outside their own group: 27 percent of adult Hispanics, 30 percent of Asians, and 35 percent of African Americans have dated across racial lines. ${ }^{43}$

An unsurprising consequence of rising intermarriage is the increasing number and proportion of demographically mixed race children. Among children below age 18 in married couple families, fewer than one percent had parents of different races in 1970, compared with 6.7 percent in 2000. Furthermore, since interracial unions are about twice as common among 
unmarried partners as among spouses, the number of mixed-race children born outside married couple families is rising even more rapidly. As of 1997, 14 percent of births in California were multiracial or multiethnic, ${ }^{44}$ and the proportion is surely higher by now. Almost half of the 6.7 million people identified with more than one race in census 2000 were under age 18.

Since families are not comprised only of parents and children, a single intermarriage or interracial child can have an impact well beyond the nuclear family. The number of White and Black Americans with a family member or close kin of a different race is increasing exponentially. The proportions among Asian Americans and American Indians are approaching 100 percent. Table 1 shows the pattern:

[Table 1 about here]

The calculations in Table 1 exclude marriages or offspring involving Latinos, or individuals who have multiracial ancestry but consider themselves to be members of one racial group. Even so, in 2000, "the fraction of Whites with kinship networks that cross either racial or Hispanic ethnic lines is nearing one-half," using the less conservative estimate of 14.4 marriages over three generations. ${ }^{45}$ By some reasonable measures, then, half of Americans have a family member of a different racial group from their own.

Normative Support for Multiracialism: As literal interacialism increases, so does normative acceptance. Until a few decades ago, some Whites described racially mixed individuals as an detestable corruption of the natural order: half-breeds, "a scourge to both races," and so on. ${ }^{46}$ That abhorrence did not, of course, stop (often forced) interracial intercourse; as journalists for the Black press repeatedly observed, "it was the Southern white man who tipped the scales of social intimacy so far until it is now at times, in certain sections, hard to tell where the white race starts and the colored race begins." 47 But Whites' predominant ideological stance was clear.

As we noted earlier, they were backed by the law and an elaborate system of social practices and institutions. Gunnar Myrdal noted bemusedly that "sex becomes... the principle around which the whole structure of segregation of the Negroes - down to disfranchisement and denial of equal opportunities on the labor marker-- is organized." 48 The Supreme Court ignored interracial marriage in the years after Brown v. Board of Education on the grounds that, as Justice Harlan is reported to have said, "One bombshell at a time is enough." (Thurgood Marshall apparently concurred.) Only 4 percent of American adults approved of interracial marriage in a 1958 Gallup poll. ${ }^{49}$ That is not an ambiguous norm or practice.

Forty years later, the norm was equally unambiguous - but reversed. In 2007, the analogous Gallup question found 77 percent approval, including 75 percent of Whites, 85 percent of Blacks, and 87 percent of Hispanics. Fully 86 percent of Whites under age 50 concurred. More liberals than conservatives approved, but almost as many Republicans as Democrats. Almost a decade earlier, more than three-fifths of respondents had endorsed interracial marriages "because they help break down racial barriers." Similar proportions found it "good for the country for more Americans to think of themselves as multiracial." Most interesting, perhaps, is that respondents dramatically exaggerated the proportion of American multiracial identifiers. Thirteen percent guessed that at least seven in ten define themselves as multiracial, and almost 80 percent guessed that a fifth of Americans do so. ${ }^{50}$ They were wrong, but seemed undisturbed by their overestimates.

Cultural Trends: It is hard to canvass cultural trends systematically, but a good indicator is the fact that actors with economic incentives find multiracialism to be worth their attention. Book publishers provide one example. After eliminating books that did not refer to individuals, we identified twenty-six in the decade of the 1990s on Amazon.com that included "multiracial," 
"biracial," "mixed race," "mulatto," or "racial mixture" in the titles. In the 2000s so far, there are more than sixty such books. Mass-audience magazines provide additional evidence. The cover of Parade magazine shows a group of smiling, adorable children under the headline of "The Changing Faces of America;" the New York Times "Style" section showcases "Generation E.A.: Ethnically Ambiguous;" and Newsweek portrays yet another set of adorable children in a cover story on "The New Face of Race." More systematically, for the 1990s, lexis-nexis identified 1890 usages in magazines of the same five keywords as for the Amazon.com search, and 2826 so far in the 2000s (as of June 12, 2009). The industry trade press showed the same pattern, more dramatically: 284 lexis-nexis usages of the five keywords in the 1990s, and 1032 so far in the 2000s.

Food packagers targeting a mass market also reveal the cultural diffusion of multiracialism:

To see the new face of the United States,... look at a box of Betty Crocker-brand food

products. Betty's portrait is now in its eighth incarnation since the first composite

painting debuted in 1936 with pale skin and blue eyes. Her new look is brown-eyed and

dark-haired. She has a duskier complexion..., with features representing an amalgam of

White, Hispanic, Indian, African and Asian ancestry. A computer created this new Betty in the mid-1990s by blending photos of 75 diverse women. ${ }^{51}$

NOTE TO EDITOR: We have some good images of multiracial children, morphed Betty

Crocker, ads aimed at mr's etc. if there is space for some images. JH and VW

Finally, market research firms, by definition, aspire to the closest connection with emerging cultural trends. One example suffices here: a claim to "anticipate the enormous demographic shift already underway in the U.S." In this "new... market, it is essential to get beyond ethnic segmentation and understand that it is the very intermingling of cultures and ethnicities that defines the... sensibility." Its peroration asks a home question: "Will you [our clients] be ready for this new, multi-colored, multi-cultural, multi-ethnic, and multi-lingual general market?",52

In short, even before Obama's presidential candidacy, multiracialism had arrived on the American public scene - demographically, normatively, behaviorally, culturally, and economically. To the degree that a feedback effect is reinforced or even permitted by the fact that it accords with societal trends, the new racial classification policy has received an unambiguous boost. In that sense only, contemporary multiracialism is analogous to the old onedrop-of-blood laws and the 1970 invention of Hispanic - and not analogous to the categories of mulatto or the Mexican race.

\section{The Political Balance: Identification with and Hostility to Racial Mixture}

The theory of a policy-politics feedback loop holds that a new policy creates a political constituency or fact on the ground, which then enables the policy to become sufficiently embedded that it survives its original context. That is, the newly institutionalized policy needs supporters with incentives to maintain and deepen it, or it must become so much a part of citizens' daily lives that rescinding it becomes politically unthinkable. ${ }^{53}$ To continue with our examples, the category of Hispanic developed a strong constituency, and the southern one-drop rules became an unexamined part of everyday life; both have survived.

Conversely, for the feedback loop to take hold, political opposition to the new policy must be weak enough that it can be consistently overcome, or it must be of the sort that actually galvanizes constituents into stronger support of rather than undermining their commitments to the new policy. The Mexican race ran into strong opposition and had almost no constituency; it disappeared at once. The mulatto category eventually lost its white constituency and succumbed 
to political opponents seeking racial purity; it too was removed from the official classification system.

In the case of the new policy of recognizing racial mixture, overtly political constituent development remains uncertain, while the entry of multiracialism into citizens' daily lives might be occurring, albeit slowly. Overt political opposition has diminished and is likely to remain weak. But group loyalties persist; they could either sap the strength of multicultural identity or change the way in which large numbers of Americans understand and practice racial politics. The political arena, in short, remains complicated and volatile.

Multiracial Self-definition: Most Americans do not see themselves as multiracial, at least as evidenced in classification systems. Analyses of the 2000 census and subsequent American Community Surveys (ACS) led sociologist Reynolds Farley to conclude in 2004 that "identifying with multiple races [was] a social movement that succeeded but failed.... I doubt... that 'multiracial' will be commonly used as if it were a race, either when people identify themselves or when agencies and courts wrestle with equal opportunities for all races." "54 Farley's conclusion, however, may have been premature. Figure 4 updates and extends his findings, using two sets of census calculations and another large, repeated survey:

[Figure 4 about here]

One must be cautious about these data for several reasons. ${ }^{55}$ Nevertheless, these series provide the best available evidence, and they all show the same basic facts: identification with two or more races is low, and has been rising since 2005.

Disaggregating these data provides reasons to expect mixed race identification to continue to rise. The category of Black + another race is the most politically and emotionally fraught. Yet the proportion of people choosing Black + another race rose from 4.8 percent in 2000 to 6.5 percent in the 2008 ACS. The proportion of American Indians + another race similarly rose, from 39.9 to 48.5 percent. And the proportion choosing SOR + a named race declined dramatically, from 17.1 to 8.3 percent, suggesting that multiracialism is less frequently a stand-in for White Hispanics than it was a few years ago. ${ }^{56}$

Another reason to anticipate a rise in mixed race identification is that people under age 18 disproportionately call themselves (or are labeled by their parents as) multiracial. Barely two percent of adults identified with more than one race in the 2000 census, compared with twice as many of those under 18. In the 2008 ACS, the ratio was three to one. Put another way, a quarter of the American population was under age 18 in 2008, whereas almost half of the two-or-moreraces population was. ${ }^{57}$ As Figure 4 shows, the NHIS shows the same relative youthful overrepresentation. If these young people retain mixed race identity in adulthood and pass it on to their children, and given that future birth cohorts will have more mixed race children since interracial marriage is rising, the proportion of self-defined multiracials will likely increase.

The proportion of self-identified multiracials is sometimes much higher in recent smaller surveys. In order to investigate a more "fluid portrait of ethno-racial self-identification," Taeku Lee asked respondents in a 2003 California survey to allocate ten points among racial or ethnic groups to indicate their own group heritage. Just over a quarter gave at least one point to more than one group. As Lee points out, "this is several magnitudes of order greater than the proportion of multi-racial identifiers we find using categorical measures." In 2009, Newsweek found that 16 percent of its respondents considered themselves to "be of mixed race." Eleven percent have a mixed race child; a quarter have a close family member with a spouse or partner of a different race; and very large majorities know someone of mixed race or an interracial couple. ${ }^{58}$ 
Mixed race identification might also rise because the United States' future high-status adults have a relatively high propensity to define themselves in terms of more than one race. Fully 17 percent of participants in a survey of first-year students at selective colleges and universities who were identified by their institution as Black reported being of mixed race. Comparable figures for Latinos were 28.2 percent, for Asians 7.4 percent, and for Whites 1.7 percent. In 2007, 8.3 percent of the roughly 48,000 students in 31 highly selective private American colleges and universities (in some cases the same schools) identified with more than one race. ${ }^{59}$

Scholars at UCLA have surveyed hundreds of thousands of full-time, first-year students attending American colleges and universities for decades, and have permitted them to choose more than one race since 1971. Figure 5 shows the pattern for all students, based on the weighted sample and including Hispanic as a "race" analogous to Black, White, Asian, and American Indian.

[Figure 5 about here]

By 2007, over 8 percent of students entering American colleges identified with more than one of these groups; the rise since 1990 has been uneven but unmistakable, and no evidence points to reversal.

Multiracial self-identification might also increase due to the fact that the proportion of Americans who are Hispanic is rising, and Hispanics have a long cultural tradition of defining themselves as multiracial. Probably few Latinos are conversant with José Vasconcelos's vision of la raza cósmica, but many might recognize themselves in his description of a group with mingled White, Black, and American Indian ancestry. In the 2001 Children of Immigrants Longitudinal Study, for example, which involves a sample of young adults in two highly diverse American cities, 11 percent defined themselves as multiracial. ${ }^{60}$

Finally, more people may define themselves in terms of more than one race for the simple reason that the possibility is becoming more available. As people moving into adulthood are routinely offered the option of choosing multiple races or "multiracial" when they register for school, apply to college, get a driver's license, apply for a job, join the military, fill out federal forms, answer surveys, or go to a doctor, it could become simply an uncomplicatedly appropriate option to an increasing number of Americans. After all, young adults see highly visible figures from Barack Obama through Tiger Woods and Halle Berry identify as multiracial; these young adults are embedded in increasingly diversified kinship networks; they are becoming more likely to come across interracial couples and their children; and they are encountering ever more attention to multiracialism from commercial enterprises. For all of these reasons, defining oneself in terms of multiple races is likely to spread through the American population, slowly perhaps but steadily.

Even if that expectation is met, the conditions for a robust policy-politics feedback loop are not yet satisfied. For a new classification system to really take hold and help to shape the policy, it needs a politically strong constituency that moves beyond simple acceptance of a new set of boxes to check. Identification, that is, must become identity of some sort.

Resistance to Multiracial Identity: Much research has examined whether immigrants and their descendents from Latin America or Asia come to identify as Hispanics or Asian Americans instead of continuing to understand themselves and practice politics with reference to their nationality of origin. ${ }^{61}$ That is, are they developing a racial identity analogous to that of African Americans? Perhaps, and that is precisely what opponents feared when the issue of 
multiracialism reached the political agenda in the 1990s. Some opponents were vehement, such as Representative Eleanor Holmes Norton (D-DC):

At one point, blacks thought they might mitigate the effects of being black by claiming something else in their heritage. 'Oh, I am black, but I am also American Indian...' Oh, it was so pitiful. About the only thing that American racism did for us is saying, 'No, you are one or the other...' So I sit here as a light skin black woman and I sit here to tell you that I am black. That people who are my color in this country will always be treated as black.... We who are black have got to say, 'Look, we are people of color, and we are readily identified. Any discrimination against one of us is discrimination against another.'

Others were cool and legalistic, as was Harold McDougall of the NAACP:

Overcoming the long history of discrimination in employment, lending, housing, and education requires that demographic data be kept on racial and ethnic groups who have historically been the targets of discrimination by members of the European-American majority group.... Thus the creation of a multiracial classification might disaggregate the apparent numbers of members of discrete minority groups, diluting benefits to which they are entitled as a protective class under civil rights laws and under the Constitution itself. In our quest for self-identification, we must take care not to recreate, reinforce or even expand the caste system we are all trying so hard to overcome. ${ }^{62}$

Only one of the thirty-nine members of the Congressional Black Caucus supported recognition of racial mixture in the late 1990s.

We coded the testimony at the 1993 and 1997 Congressional hearings on proposed changes in the federal system of racial classification, and found at least fifteen distinct arguments among the fifty-eight speakers. Opponents most commonly concurred with Rep. Norton, that multiracialism was merely a way to escape identification with a disfavored race or ethnicity. Their second most common claim echoed Mr. McDougall's, that the change would undermine enforcement of civil rights or voting rights laws. Supporters frequently contradicted the latter view, arguing that the new classification system would enhance civil rights or voting rights enforcement. But many endorsed a version of the former claim, that the new classification system would enable people to choose a new identity; that was their goal. ${ }^{63}$

Surely few Americans of any race attended to Congressional hearings or OMB decisions about the forthcoming census. But the issue moved into the public arena. During the month of census enumeration, Ebony Magazine, with a circulation of about 1.5 million, urged readers to "actively take part in the 2000 Census," on grounds articulated by "the highest-ranking Black at the Census:" it is "a matter of pride. There's the whole issue of respect. When you have the numbers, people listen." Ebony went on, however, to describe one concern African-American leaders continue to have with the census form..., the question of race. William Spriggs, director of research and public policy for the National Urban League, says that the question is worded in a way that would force many Blacks to check several boxes, which would lead to a Black person being counted as 'other' instead of African-American. One rule of thumb, Spriggs says: 'If you get treated like you're Black, then check Black. ${ }^{, 64}$

Few Blacks did, in fact, choose more than one race.

After 2000, racial advocacy groups were less vocal, though not silent, on the issue of multiracial classification. In 2005 the Mexican American Legal Defense Fund (MALDEF) and the Reverend Jesse Jackson protested the EEOC's plan to add a category of "two or more races" 
to employers' reporting forms. Speaking as groups "concerned about the advancement of people of color," they formally expressed their concern that "the category of 'Two or more races' would not be meaningful for affirmative action purposes under OFCCP's [Office of Federal Contract Compliance Programs] authority." Two years later, the Department of Education reported similarly: "Some commentators suggested that reporting two or more races will have a detrimental impact on compliance with, and enforcement of, civil rights laws; ignores OMB guidance for aggregation and allocation of multiple race responses for purposes of civil rights reporting; and limits public access to important information by civil rights advocates, parents, and others." 65 Sprinkled through the Federal Register are similar expressions of continuing concern and monitoring.

Overt opposition to recognition of or identification with more than one race has declined further since Barack Obama's candidacy and electoral victory. Some continue to worry that parents who define their children as mixed race "set up their kids for a life of minefields and rejections. It's (unintentionally) cruel, selfish and shortsighted to produce multiracial children in a predominantly racist society." ${ }^{, 66}$ But most explicit rejection of multiracialism has dissipated. Multiracial Advocacy: Despite the decline in overt opposition, as identities are usually defined, multiracial identity remains weak. For example, multiracial groups are less involved in advocacy than they were a decade ago, and are waning. Kim Williams located about sixty local and national groups in the 1990s that publicly promoted multiracialism. ${ }^{67}$ Using the Encyclopedia of Associations, internet searches, and listings on other group websites, we found 109 named groups in 2008. That looks like evidence of increasing robustness, but it is not. Only twenty-one had an active website, some of which had not been updated for at least a year. Over half had no publicly listed e-mail address or telephone number. Only ten of the 109 groups featured any political activism such as discussions of policy issues or efforts to educate legislators about multiracial rights; the most common specified goal was to "organize social gatherings where members can relax, share our experiences, and learn from the experiences of others," in the words of Montclair, New Jersey's Getting Interracial Families Together. To our knowledge, multiracial groups have not sought further changes in the federal statistical system or testified in hearings on the 2010 census.

Thus unlike in the case of social security and AARP, ${ }^{68}$ or the case of Hispanics and MALDEF or La Raza, for example, consolidation of multiracial identifiers into a powerful constituent group that politicians cannot afford to ignore or flout is not occurring.

Multiracial Identity: More analytically, multiracialism functions politically neither like interests represented by lobbies nor like race with its array of supportive organizations. On interests: people who gain materially from a new policy have an incentive to find each other and form an organized constituency to support consolidation -- that is, to create a vigorous policy-politics feedback loop. But identifying as multiracial provides no material policy gains; no policies designed to compensate disadvantaged minorities for past injustices, such as affirmative action, majority-minority electoral districting, or small business set-asides, include people of more than one race as a designated category. Nor do universities or corporations seeking diversity include "multiracial" as a component of their desired membership.

On race: in the decades after Americans decided to treat race as a few exclusive, exhaustive groups, a powerful set of norms, emotions, and cognitive maps developed. As scholars and activists have consistently noted, many non-Whites now have a strong group consciousness, group loyalty, and perception of linked fate. These values are often associated with distinctive political and policy views. ${ }^{69}$ Thus, if framed in opposition to monoracial loyalty, 
multiracial identity is unlikely to grow much even among those who define themselves in terms of more than one race. A classification or interpretive policy is simply too weak to develop a politics on its own; at least in the foreseeable future, we do not expect to see a strong form of multiracial identity in which people think of themselves as multiracial rather than some other race, experience life in arenas such as work, school, or politics distinctively, feel a special attachment to other multiracials, and unite in the political or public arena. People with Black and White ancestry, for example, seldom feel part of the same group as people with Asian and Hispanic ancestry.

But multiracial identity need not be perceived or felt as a new racial group identity analogous to being Black, White, or Asian in order to affect the American racial order. It can be understood as an addition rather than an alternative, a contextual choice rather than a fixed characteristic, a way of remaining connected to two (or more) poles rather than choosing one instead of the other. That, at any rate, is what prominent proponents of multiracialism appear to believe.

In 2005, then-Senator Barack Obama emphasized the link between racial identity and multiracial identity: "I don't think you can consider the issue of mixed race outside of the issue of race. I think it's important to try to avoid that sense of exclusivity.... Don't ever think of yourself as so unique that you divorce yourself from your communities."70 A decade earlier, Maria Root's widely-disseminated "Bill of Rights for People of Mixed Heritage" emphasized context and fluidity: mixed race people have the rights "not to be responsible for people's discomfort with my physical or ethnic ambiguity," "to identify myself differently in different situations," "to change my identity over my lifetime--and more than once," and "to have loyalties and identification with more than one group of people."71 These claims have a very different tone from assertions of linked fate, racial solidarity, or group interests.

Little direct evidence exists on whether this distinctive understanding of multiracial identity, and therefore of race as a whole, is growing. But indicators are suggestive. To begin with, many Americans, presumably including people with a strong racial identity, endorse recognition of multiple ancestries; as early as 1995, 49 percent of Black and 36 percent of White survey respondents agreed that "the US Census should add a 'multiracial' category to population surveys so some people aren't forced to deny part of a family member's heritage by having to choose a single racial category." ${ }^{, 72}$ In addition, at least some multiracial groups explicitly resist conventional understandings of races as exhaustive and exclusive. Three groups representing mixed race people recently objected to a "multiracial" item on the University of California system's application form, on the grounds that a single category would limit "their choice to a generic multiracial/multiethnic category [that] ignores this diversity and severely limits the ability of UC to gain a clear and detailed picture of its student population." They wanted the form to allow multiple choices so that students' racial identities would be noted along with their mixed race identification. The MAVIN Foundation sounds the same note in its mission statement; it is

committed to creating a society that recognizes the complexity of race, racism and identity. We support the right to self-identify, and think it's important for mixed heritage and transracially adopted people to strengthen their involvement in existing ethnic and affinity communities. Although we reject exclusive and outdated notions of race, we see our work as part of a larger movement to end discrimination and inequality on individual and systemic levels. 
A spokesperson for MALDEF had made the same point many years earlier; he was "hard pressed to find a situation where understanding diversity better, understanding complexity better, is a hindrance." 73

It is not surprising, therefore, that psychologists find self-defined multiracials to be more likely than others to see race as a social construction and as a fluid concept. ${ }^{74}$ Multiracials have unusually diverse friendship networks, and are more comfortable in interracial relationships. ${ }^{75}$ As early as 1995, they endorsed interracial dating more than did Blacks and Whites, and they were less likely than Blacks to agree that Blacks should be seen as a single racial group. ${ }^{76}$ In the CILS survey, young adult multiracials are more likely to marry other multiracials than are monoracial respondents - but they are also more likely to marry Blacks, Asians, and people from "Other" races than are respondents not in those groups. ${ }^{77}$ In all of these ways, they are signaling that multiracial identity blurs, but need not dissolve, traditional racial commitments.

Possibilities for a fluid and additive multiracial identity are bolstered by the fact that monoracial group identities may be weakening. In the 1995 poll in which many Americans endorsed a multiracial category, a third of Blacks and almost three-fifths of Whites agreed that "Black Americans today have such differing mixtures of African and European ancestry that it no longer makes much sense to think of them as Black and members of a single racial group." In 2007, 37 percent of Blacks agreed that "Blacks today can no longer be thought of as a single race because the Black community is so diverse." 78

Finally, the scant survey data available supports the metaphor of this population as a bridge between more polarized groups. For example, in a 1995 survey, a twelve point gap separated monoracial Blacks and Whites when asked if racial relations were poor in the United States; mixed-race respondents were right between, not as likely to see poor race relations as Blacks but not as optimistic as Whites. ${ }^{79}$ In a smaller 2001 survey, when asked if "too little attention is paid to race and racial issues" and if there are "still major problems facing minorities in this country," multiracials again fell between the racial poles, more likely than Whites but less likely than Blacks to agree with both claims. ${ }^{80}$ The national survey by the Higher Education Research Institute at UCLA asked first-year college students how important "helping to promote racial understanding" was to them. As is typically the case, Whites were less committed to this goal than were Blacks, with 29 percent of the former and over 60 percent of the latter agreeing that promoting racial understanding was 'essential' or 'very important' to them. In contrast, the two largest sets of multiracial respondents - white/Hispanic and White/Asian - fell in between, with 36 and 39 percent agreement, respectively. ${ }^{81}$ In the National Longitudinal Survey of Freshmen, people who described themselves as Black + some other race or Hispanic + some other race were less likely than monoracial Blacks or Hispanics to express a sense of racial linked fate, more likely to see a promising racial future with less discrimination, and less likely to agree that one should vote for a co-racial candidate, shop at co-racially owned stores, have friends primarily in one's own group, and so on. ${ }^{82}$ Consistently across these surveys, multiracials' support for affirmative action measures, racial redistricting, or government intervention to ensure equality falls between that of Blacks and Whites. So do their perceptions of racial tension and disenfranchisement. ${ }^{83}$ If the results of these initial surveys hold up over time and in the political arena, people who describe themselves as multiracial, even if they do not develop a strong group-based identity, may come to occupy a middle ground between traditional racial poles. Like President Obama, they may take as one of their missions to be an interlocutor and compromising voice when still heated debates over race flare up. Whether they (or he) can succeed, of course, remains an open question. 
Development of a strong, shared multiracial identity would be the final phase of an emergent policy-politics feedback loop. But even if it develops, arguably this identity will not be the same kind of sentiment as a strong Black, Asian, White, or Hispanic identity. Ironically, in this way if no other, the closest analogy for contemporary multiracials may be turn-of-thecentury mulattoes or Whites distinguished by mother tongue or mixed parentage; none of these groups abjured a monoracial identity but all added something to it that distinguished them in meaningful ways from people with a single ancestry and moved them closer to another group. Analysts and activists should remain open to the possibility that the "mutts," as Barack Obama referred to people like himself, believe and behave differently than the purebreds, without being any less members of the same species.

\section{The Possible Futures of American Multiracialism}

The significance of race as we know it in today's legal and governmental categories will be obsolete in less than 20 years. The rise of mixed-race voters will dilute the racial identity politics that have become prevalent in past elections.

After, though not before, the 1920s, Americans settled on an understanding of race that revolved around a few exhaustive and mutually exclusive groups with bright lines between them. Although it was historically unprecedented and very unusual in comparison with other countries, this understanding still sets the stage for Americans' political disputes around race. The evolving multiracial movement challenges this understanding of race -- not by proposing an addition to the small set of recognized races but by undermining the sharp distinctions implied by one-drop rules and one-choice classification systems. If supporters of multiracialism succeed in their challenge, what is now a small, anomalous annoyance to statisticians and advocacy groups could change much of the politics and policy of American race relations.

History teaches us to refrain from any strong prediction; too many racial classifications, even some that lasted almost a century, have come and gone. "Mark one or more" could go the way of mulatto, the Mexican race, half-breeds, mother tongue, Hindoos, mixed parentage, and other efforts to classify and make sense of the United States' wonderfully complex mix of people. Nevertheless, although some aspects of multiracialism are spreading faster than others, we are reasonably confident that enough feedbacks have taken hold to reinforce the trajectory of self-defined mixture. As public and private actors move to a "mark one or more" classification system, as racial mixture increases demographically and multiracial identification grows socially, and as opposition to the new formulation wanes, returning to the twentieth century racial order becomes increasingly unlikely.

To what end? Permitting people to connect with more than one race seems like a small move, but it may set a new path for racial development in the United States. Perhaps most importantly and not coincidentally, multiracial identification can reinforce a significant cohort change. Evidence shows consistently that many members of the generation coming of age during the Obama era see racial difference as less important, or differently important, than their elders do. Young adults do not share a collective racial memory that revolves around civil rights battles, the urgent need for group solidarity, and the sharp antagonisms that result from losing dominance. Instead, young adults' most vivid racial memory may be the election and power of a biracial president who received more support from all groups than did his recent Democratic predecessors. The United States is certainly not post-racial after November 2008, but it is arguably more multiracial - and if the new collective racial memory persists and deepens among 
young adults, a perception of identity as additive rather than substitutive may well produce feedbacks of its own.

There will be costs to such a future. Desperately poor people of color may be left without the language of group solidarity and pride that has for decades provided a partial weapon against and insight into their situation. Claims of race-based discrimination and profiling could be met with even more skepticism than they meet with now, and may be harder to prove in court. Racially-inflected inequality may persist and be harder to pinpoint and rectify. For worse as well as for better, however, Americans appear to be moving away from the last century's racial order. Who will benefit, and who will pay the price, remains to be seen - perhaps by our children. 
Table 1: Estimated Percentage of Americans Belonging to Mixed-race Kinship Networks, by Race and Decade

\begin{tabular}{ccccc}
\hline & White & Black & Asian American & American Indian \\
\hline 1960 & 1.9 & 9.2 & 81.1 & 89.6 \\
1970 & 3.6 & 10.9 & 87.5 & 99.0 \\
1980 & 9.8 & 21.9 & 91.5 & 99.9 \\
1990 & 9.0 & 28.3 & 79.5 & 99.8 \\
2000 & 22.4 & 49.8 & 83.9 & 100 \\
\hline
\end{tabular}

Note: Results are based on kinship network size of 10 marriages over three generations. With a less conservative estimate of 14.4 marriages over three generations, 30.5 percent of Whites, 62.9 percent of Blacks, and 92.8 percent of Asian Americans had kin of a different race in 2000.

Source: Joshua Goldstein, communication with the authors, January 29, 2009. See also (Goldstein 1999). 
Figure 1: Tabulation Plan for Spanish Heritage Definition, 1970 Census

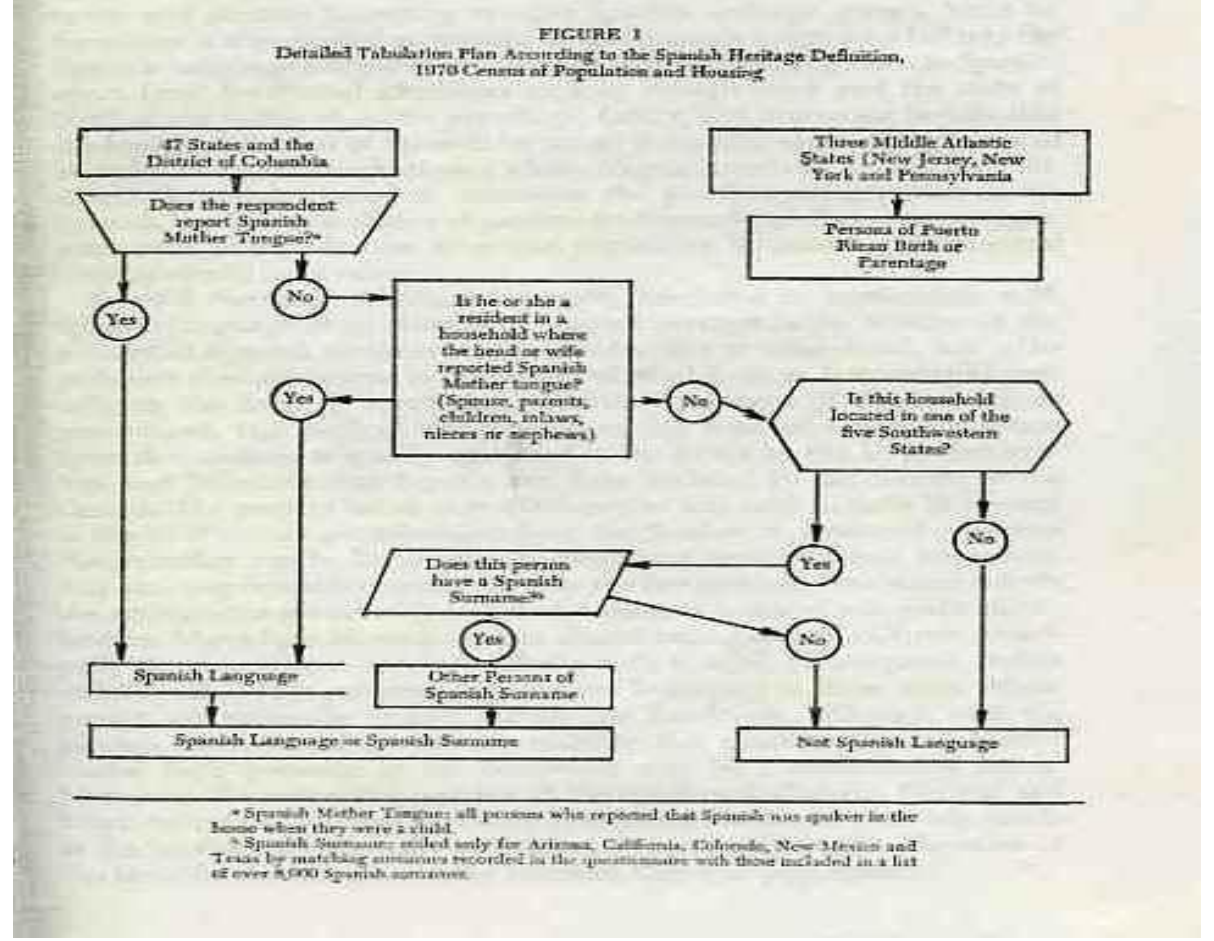

Source: (Hernandez et al. 1973): 675. 
Figure 2: Explaining Boundaries between Negroes and Whites, 1910

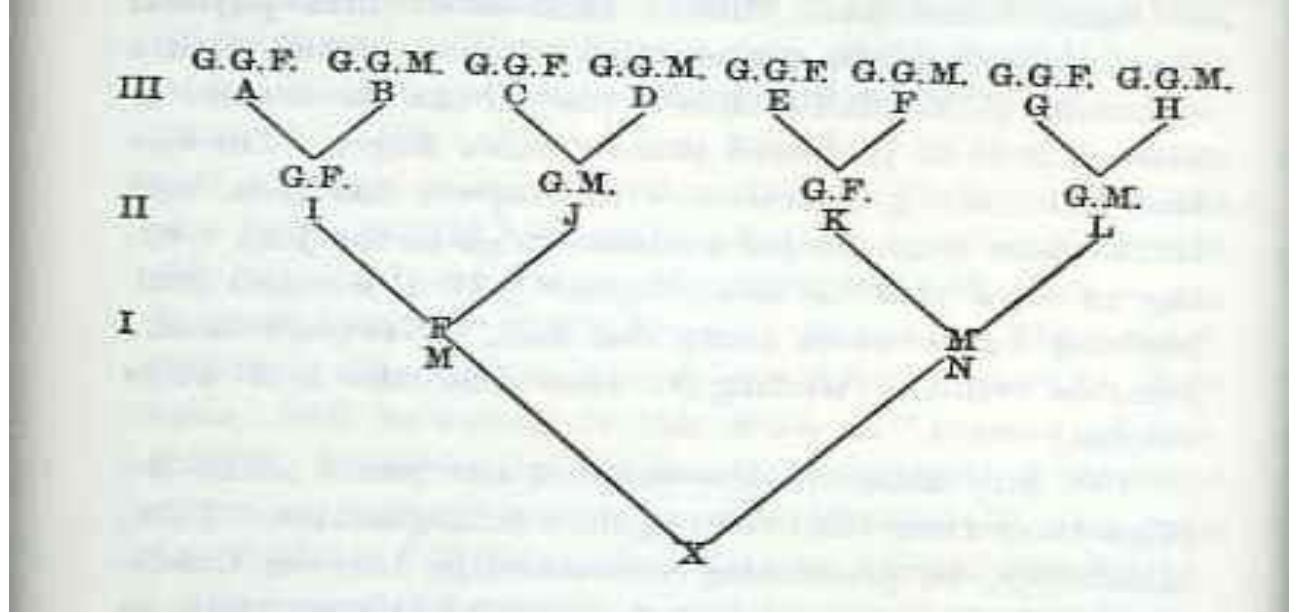

Source: Stephenson 1910, 18 
Figure 3: Interracial Marriage Rates, 1880-2000
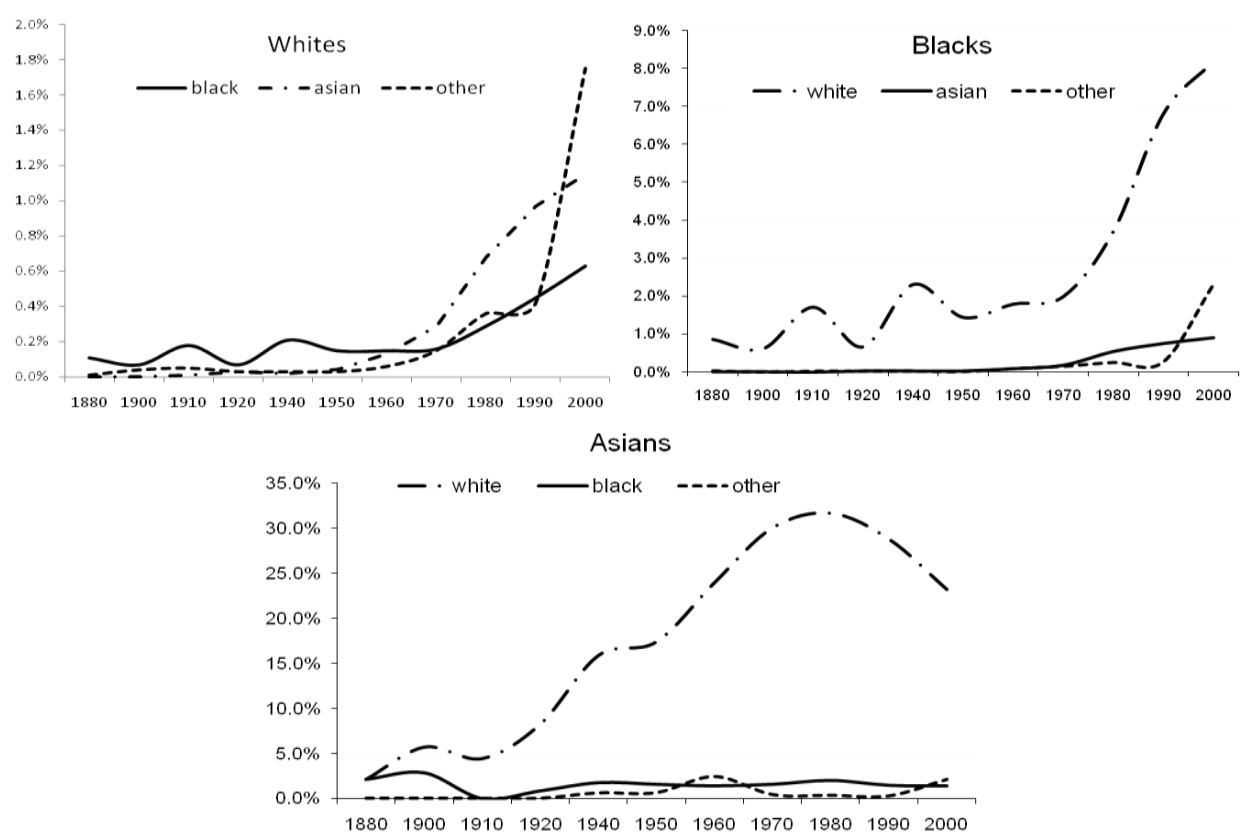

Source: Adapted from (Fryer Jr. 2007) 
Figure 4: Identification with Racial Mixture in Key Surveys ${ }^{85}$

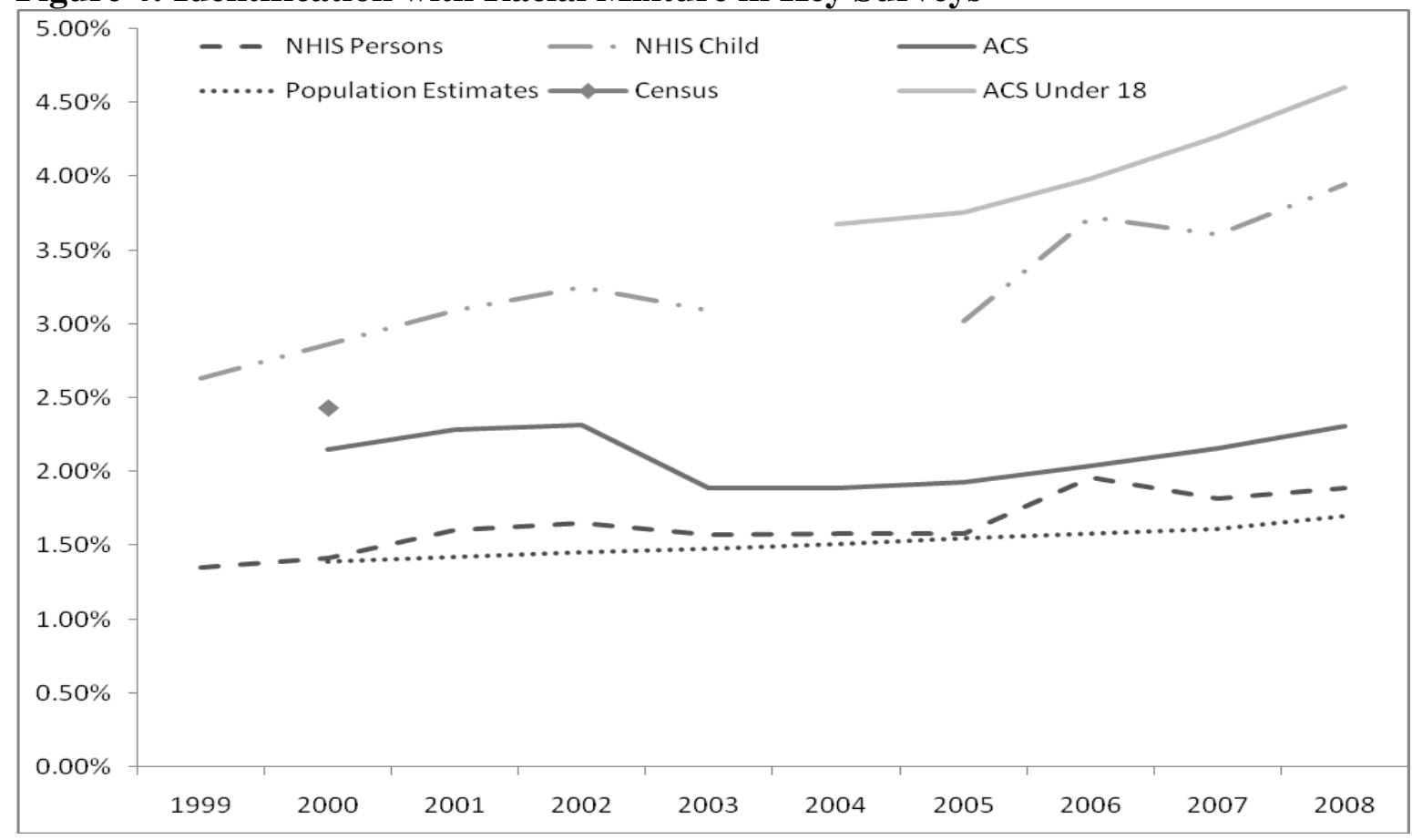

Sources: 1) U.S. Census 2000, at:

(factfinder.census.gov/servlet/AdvSearchByKeywordServlet?_lang=en;

American Community Survey, at: (www.census.gov/acs/www/index.html);

Population Estimates at (U. S. Bureau of the Census 2009 ); various codebooks for NHIS, 19992008. In the NHIS and ACS, those under 18 are a subset of the broader sample. 
Figure 5: \% Two or More Races, HERI College Freshmen Survey, 1971-2008

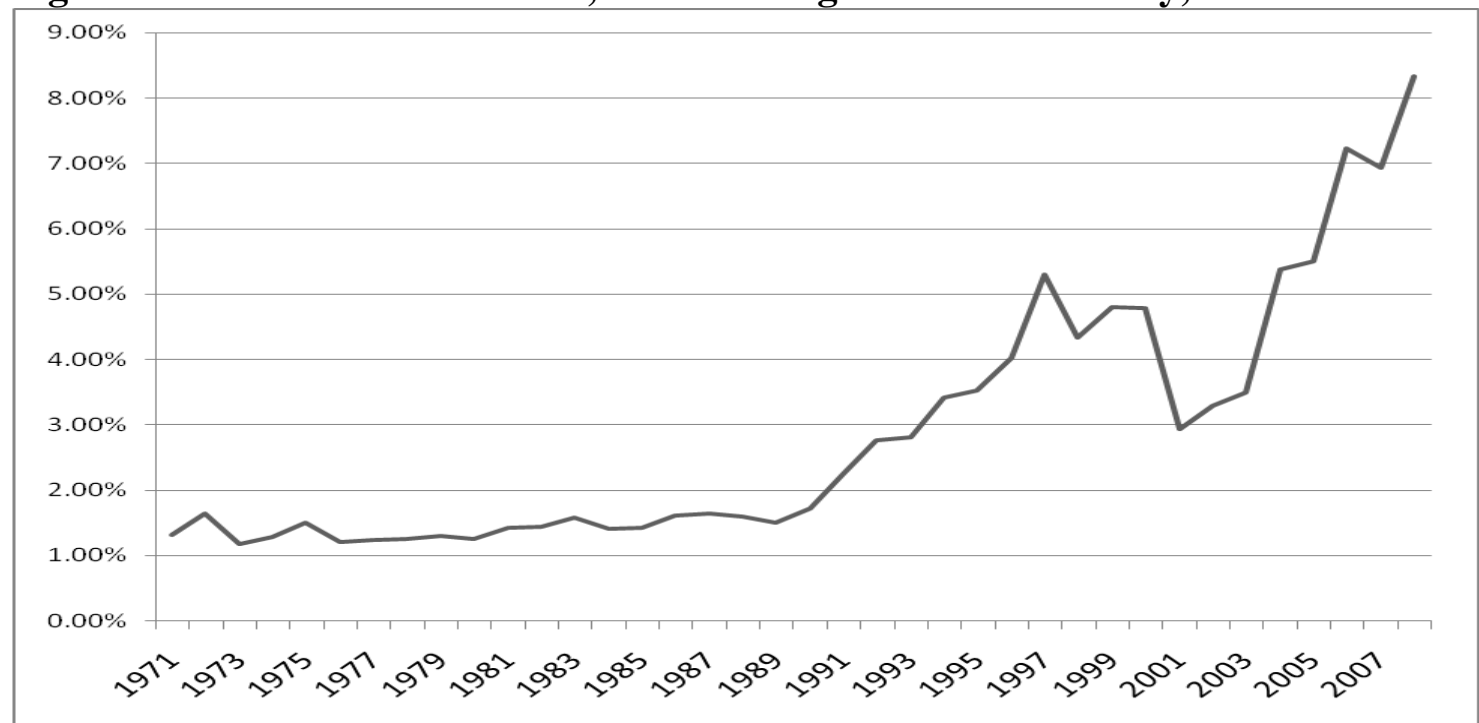

Source: analysis for the authors by HERI staff. CIRP Freshman Survey, Higher Education Research Institute at UCLA, 1971 to 2008. Data include only full-time students at 4-year institutions, and institutions with at least a 60 percent participation rate. Sample sizes range from 142,000 to 286,000 , in hundreds of institutions chosen by a careful stratification system.

\section{References}

"Why the Census is Important to You" (2000). Ebony, April, pp. 31ff. Anderson, Benedict (2002). The Spectre of Comparison. London: Verso.

Andrews, Matthew and Jeffrey Chun (2007). "(Mis)Educating About 'Mixed Race': Discourse on Multiraciality and the Prospects of Higher Education Policy." Asian American Policy Review 16(xx): 87-94.

Aoki, Andrew and Okiyoshi Takeda (2009). Asian American Politics. New York??: Polity Press. Bratter, Jenifer and Karl Eschbach (2006). "'What About the Couple?' Interracial Marriage and Psychological Distress." Social Science Research 35(4): 1025-47.

Broh, C. Anthony and Stephen Minicucci (2008). Racial Identity and Government Classification: A Better Solution. Association for Institutional Research, Seattle WA,May 28.

Campbell, Andrea (2003). How Policies Make Citizens: Senior Political Activism and the American Welfare State. Princeton NJ: Princeton University Press.

Chandler, Michael and Maria Glod (2009). "Multiracial Pupils to Be Counted in a New Way." Washington Post. March 23, pp. A1.

Chong, Dennis and Reuel Rogers (2004). "Reviving Group Consciousness." The Politics of Democratic Inclusion. C. Wolbrecht and R. Hero. Philadelphia PA: Temple University Press: $45-74$.

Cooperative Institutional Research Program (various). Freshman Survey. Los Angeles, CA: UCLA, Graduate School of Education and Information Services, Higher Education Research Institute

DaCosta, Kimberly (2004). "All in the Family: The Familial Roots of Racial Division." The Politics of Multiracialism. H. Dalmadge. Albany NY: State University of New York Press: $19-41$. 
Dawson, Michael (1994). Behind the Mule: Race and Class in African-American Politics. Princeton NJ: Princeton University Press.

Department of Education (2007). "Final Guidance on Maintaining, Collecting, and Reporting Racial and Ethnic Data to the U.S. Department of Education" " Federal Register 72(202): 59266-79.

Edmonston, Barryet al. (1996). Spotlight on Heterogeneity: The Federal Standards for Racial and Ethnic Classification. Washington D.C.: National Academy Press.

Edmonston, Barry and Charles Schultze (1995). Modernizing the U.S. Census. Washington, D.C.: National Academy Press.

Espiritu, Yen Le (1992). Asian American Panethnicity : Bridging Institutions and Identities. Philadelphia: Temple University Press.

Farley, Reynolds (2004). "Identifying with Multiple Races: A Social Movement That Succeeded but Failed?" The Changing Terrain of Race and Ethnicity. M. Krysan and A. Lewis. New York: Russell Sage Foundation: 123-48.

Farley, Reynolds (2007). The Declining Multiple Race Population of the United States: The American Community Survey, 2000 to 2005. Population Association of America, New York City,March 29-31.

Foucault, Michel (1979). Discipline and Punish. xx: Vintage Books.

Fryer Jr., Roland (2007). "Guess Who's Been Coming to Dinner? Trends in Interracial Marriage over the 20th Century." Journal of Economic Perspectives 21(2): 71-90.

Gallup. (2007, August 16, 2007). "Most Americans Approve of Interracial Marriages." Retrieved July 23, 2008, from http://www.gallup.com/poll/28417/Most-AmericansApprove-Interracial-Marriages.aspx.

Gallup/ CNN/ U.S.A. Today (2001). Poll -- March Wave 1

Garcia Bedolla, Lisa (2009). Latino Politics. New York??: Polity Press.

Goldstein, Joshua (1999). "Kinship Networks That Cross Racial Lines: The Exception or the Rule?" Demography 36(3): 399-407.

Goldstein, Joshua and Ann Morning (2000). "The Multiple-Race Population of the United States: Issues and Estimates." Proceedings of the National Academy of Sciences 97(11): 623035.

Gross, Ariela (2008). What Blood Won't Tell: A History of Race on Trial in America. Cambridge MA: Harvard University Press.

Hancock, Ange-Marie (2007). "When Multiplication Doesn't Equal Quick Addition: Examining Intersectionality as a Research Paradigm." Perspectives on Politics 5(1): 63-80.

Haney-López, Ian (2003). Racism on Trial : The Chicano Fight for Justice. Cambridge, Mass.: Belknap Press of Harvard University Press.

Haney Lopez, Ian (2003). Racism on Trial: The Chicano Fight for Justice. Cambridge MA: Harvard University Press.

Hattam, Victoria (2007). Ethnic Shadows: Jews, Latinos, and Race Politics in the United States. Chicago IL: University of Chicago Press

Hernandez, Jose' et al. (1973). "Census Data and the Problem of Conceptually Defining the Mexican American Population." Social Science Quarterly 53(4): 671-87.

Hirschman, Charleset al., Eds. (1999). The Handbook of International Migration: The American Experience. New York: Russell Sage Foundation. 
Hochschild, Jennifer and Brenna Marea Powell (2008). "Racial Reorganization and the United States Census 1850-1930: Mulattoes, Half-Breeds, Mixed Parentage, Hindoos, and the Mexican Race." Studies in American Political Development 22(1): 59-96.

Hochschild, Jenniferet al. (2008). Political Discourse on Racial Mixture: American Newspapers, 1865 to 1970. Policy History, St. Louis, Missouri,May 29-31.

Hollinger, David (2003). "Amalgamation and Hypodescent: The Question of Ethnoracial Mixture in the History of the United States." American Historical Review 108(5): 136390.

Hollinger, David (2006). Postethnic America: Beyond Multiculturalism. New York: Basic Books.

Hutchings, Vincentet al. (2005). The National Ethnic Politics Study (Neps): Ethnic Pluralism \& Politics in the 21st Century. American Association of Public Opinion Research, Miami Beach, FL,May 12.

Igo, Sarah (2007). The Averaged American: Surveys, Citizens, and the Making of a Mass Public. Cambridge MA: Harvard University Press.

Jacobson, Matthew (1998). Whiteness of a Different Color: European Immigrants and the Alchemy of Race. Cambridge MA: Harvard University Press.

Jones, Trina (2000). "Shades of Brown: The Law of Skin Color." Duke Law Journal 49: 1487557.

Joseph, Peniel (2007). Waiting 'Til the Midnight Hour: A Narrative History of Black Power in America New York: Holt.

Kasinitz, Philipet al. (2008). Inheriting the City: The Children of Immigrants Come of Age New York and Cambridge MA: Russell Sage Foundation and Harvard University Press.

King, Desmond and Rogers Smith (2005). "Racial Orders in American Political Development." American Political Science Review 99(1): 75-92.

Lee, Sharon and Barry Edmonston (2006). "Hispanic Intermarriage, Identification, and U.S. Latino Population Change." Social Science Quarterly 87(5): 1263-79.

Lee, Taeku (2004). Social Construction, Self-Identification, and the Survey Measurement of 'Race'. American Political Science Association, Chicago IL.

Lien, Pei-teet al. (2003). "The Contours and Sources of Ethnic Identity Choices among Asian Americans." Social Science Quarterly 84(2): xxxx.

Lien, Pei-teet al. (2004). The Politics of Asian Americans: Diversity and Community. New York: Routledge.

Marx, Anthony (1998). Making Race and Nation: A Comparison of South Africa, the United States, and Brazil. New York: Cambridge University Press.

Massey, Douglas and Camille Charles (2006). "National Longitudinal Survey of Freshmen." Princeton University, Office of Population Research, pp. http://nlsf.princeton.edu/index.htm.

Massey, Douglaset al. (2003). The Source of the River: The Social Origins of Freshmen at America's Selective Colleges and Universities. Princeton, NJ: Princeton University Press.

Matsuoka, Natalie (2008). "Political Attitudes and Ideologies of Multiracial Americans." Political Research Quarterly 61(2): 253-67.

McDougall, Harold (1997). Statement at Hearings on "Federal Measures of Race and Ethnicity and the Implications for the 2000 Census". Subcommittee on Government Management, Information, and Technology, Committee on Government Reform and Oversight, U.S. 
House of Representatives, 105th Cong., 1st sess. Washington D.C.: U.S. Government Printing Office: 301-16

Mettler, Suzanne (2002). "Bringing the State Back in to Civic Engagement: Policy Feedback Effects of the

G.I. Bill for World War Ii Veterans." American Political Science Review 96(2): 351-65.

Mettler, Suzanne and Joe Soss (2004). "The Consequences of Public Policy for Democratic Citizenship: Bridging Policy Studies and Mass Politics." Perspectives on Politics 2(1): $55-74$.

Montejano, David (1987). Anglos and Mexicans in the Making of Texas, 1836-1986. Austin: University of Texas Press.

Morning, Ann (2006). "Ethnic Classification in Global Perspective: A Cross-National Survey of the 2000 Census Round." Population Research and Policy Review forthcoming.

Murray, Pauli (1997 [1950]). States' Laws on Race and Color. Athens: University of Georgia Press.

Myrdal, Gunnar (1944). An American Dilemma. New York: Harper \& Brothers.

New American Media. (2007a). "California Dreamers: A Public Opinion Portrait of the Most Diverse Generation the Nation Has Known." from http://news.newamericamedia.org/news/view_custom.html?custom_page_id=340.

New American Media. (2007b). "Deep Divisions, Shared Destiny." Retrieved August 14, 2008, from

http://news.newamericamedia.org/news/view_article.html?article_id=28501933d0e5c534 4b21f9640dc13754.

Newsweek (1995a). Survey. conducted by Princeton Survey Reseach Associates

Newsweek (1995b). What Is Black? P. S. R. A. [producer]

Newsweek (2009). Survey. c. b. P. S. R. A. International

Nobles, Melissa (2000). Shades of Citizenship: Race and the Census in Modern Politics. Stanford CA: Stanford University Press.

Norton, Eleanor Holmes (1997). Statement at Hearings on "Federal Measures of Race and Ethnicity and the Implications for the 2000 Census". Subcommittee on Government Management, Information, and Technology; Committee on Government Reform and Oversight, U.S. House of Representatives, 105th Cong., 1st sess. Washington D.C.: U.S. Government Printing Office: 259-61

Novkov, Julie (2008). Racial Union: Law, Intimacy, and the White State in Alabama, 1865-1954. Ann Arbor: University of Michigan Press.

(1977). Statistical Policy Directive Number 15: Race and Ethnic Standards for Federal Statistics and Administrative Reporting. Washington D.C. :

Office of Management and Budget (1997). Revisions to the Standards for the Classification of Federal Data on Race and Ethnicity. Washington D.C.: Executive Office of the President, OMB Office of Information and Regulatory Affairs, http://www.whitehouse.gov/omb/fedreg/1997standards.html.

Pascoe, Peggy (2009). What Comes Naturally: Miscegenation Law and the Making of Race in America. Oxford ; New York: Oxford University Press.

Pew Research Center for the People and the Press (1999). Millenium Survey. C. b. P. S. R. Associates

Pew Research Center for the People and the Press. (2007). "Racial Attitudes in America." Retrieved August 20, 2008, from http://pewsocialtrends.org/assets/pdf/Race.pdf. 
Portes, Alejandro and Rubén Rumbaut (1991-2006). Children of Immigrants Longitudinal Study (Cils) [Computer File]. Icpsr20520-V1. Ann Arbor, MI: nter-university Consortium for Political and Social Research [distributor]

Powell, Brenna (2009). Grey Area: Defining Race and the Struggle for Equality in Brazil Cambridge MA: Harvard University, Government and Social Policy Program

Prewitt, Kenneth (2001). "Census 2000 and the Fuzzy Boundary Separating Politics and Science." Bulletin of the American Academy of Arts and Sciences 54(4): 32-40.

Qian, Zhenchao and Daniel Lichter (2007). "Social Boundaries and Marital Assimilation: Interpreting Trends in Racial and Ethnic Intermarriage." American Sociological Review 72(1): 68-94.

Quillian, Lincoln and Rozlyn Redd (2009). "The Friendship Networks of Multiracial Adolescents." Social Science Research 38(xx): 279-95.

Rodriguez, Gregory (2007). Mongrels, Bastards, Orphans, and Vagabonds: Mexican Immigration and the Future of Race in America. New York: Pantheon Books.

Roediger, David (2005). Working toward Whiteness. New York: Basic Books.

Sawyer, Mark (2005). Racial Politics in Post-Revolutionary Cuba. New York: Cambridge University Press.

Schor, Paul (2005). "Mobilising for Pure Prestige? Challenging Federal Census Ethnic Categories in the USA (1850-1940)." International Social Science Journal 57(183): 89101.

Schuck, Peter (2009). "Immigrants' Incorporation in the United States after 9/11: Two Steps Forward, One Step Back." Bringing Outsiders In: Transatlantic Perspectives on Immigrant Political Incorporation J. Hochschild and J. Mollenkopf. Ithaca NY: Cornell University Press: 158-75.

Scott, James (1998). Seeing Like a State: How Certain Schemes to Improve the Human Condition Have Failed. New Haven CT: Yale University Press.

Shelby, Tommie (2005). We Who Are Dark: The Philosophical Foundations of Black Solidarity. Cambridge, MA: Harvard University Press.

Shih, Margaretet al. (2007). "The Social Construction of Race: Biracial Identity and Vulnerability to Stereotypes." Cultural Diversity and Ethnic Minority Psychology 13(2): $125-33$.

Shklar, Judith (1991). American Citizenship. Cambridge MA: Harvard University Press.

Sidanius, Jimet al. (2001). "Inclusionary Discrimination: Pigmentocracy and Patriotism in the Dominican Republic." Political Psychology 22(4): 827-51.

Siegel, Jacob and Jeffrey Passel (1979). Coverage of the Hispanic Population of the United States in the 1970 Census: A Methodological Analysis. Washington D.C.: U. S. Bureau of the Census,

Simmons, Tavia and Martin O'Connell (2003). Married-Couple and Unmarried-Partner Households: 2000. Washington D.C. : U.S. Bureau of the Census,

Skerry, Peter (2000). Counting on the Census? Race, Group Identity, and the Evasion of Politics. Washington, D.C.: Brookings Institution Press.

Skrentny, John David (2002). The Minority Rights Revolution. Cambridge, Mass.: Belknap Press of Harvard University Press.

Smith, James and Barry Edmonston, Eds. (1997). The New Americans: Economic, Demographic, and Fiscal Effects of Immigration. Washington D.C.: National Academy Press. 
Smith, Rogers (2007). "Studies in American Racial Development: An Interim Report." Perspectives on Politics 5(2): 325-33.

St. James, Phillip (2007). "Letter to the Editor " Ebony, pp. 31.

Stanfield, Rochelle'. (1999, June 1999). "The Blending of the United States." Retrieved July 23, 2008, from http://usinfo.state.gov/journals/itsv/0699/ijse/stanfld.htm.

Stephenson, Gilbert (1910). Race Distinctions in American Law. New York and London: D. Appleton and Company.

Tafoya, Sonya. (2000). "Check One or More... Mixed Race and Ethnicity in California." Retrieved August 20, 2008, from http://www.ppic.org/content/pubs/cacounts/CC_100STCC.pdf.

Telles, Edward (2004). Race in Another America: The Significance of Skin Color in Brazil. Princeton NJ: Princeton University Press.

U. S. Bureau of the Census (2001). The Two or More Races Population: 2000. Washington D.C.: U.S. Department of Commerce,

U. S. Bureau of the Census (2002). Measuring America: The Decennial Censuses from 1790 to 2000. Washington D.C.: U.S. Department of Commerce,

(2009). Annual Estimates of the Resident Population by Sex, Race, and Hispanic Origin for the United States: April 1, 2000 to July 1, 2008. Washington D.C.: P. Division,

U. S. Census Office (1895). Report on Population of the United States at the Eleventh Census: 1890. Washington D.C.: Government Printing Office,

U. S. Department of Education (2007). "Final Guidance on Maintaining, Collecting, and Reporting Racial and Ethnic Data to the U. S. Department of Education." Federal Register 72(202): 59266-79.

U. S. Equal Employment Opportunity Commission (2005). "Agency Information Collection Activities: Notice of Submission for Omb Review, Final Comment Request." Federal Register 70(227): 71294-303.

Valle, Victor and Rodolfo Torres (2000). Latino Metropolis. Minneapolis: University of Minnesota Press.

Vasconcelos, José (1979 [1925]). The Cosmic Race: A Bilingual Edition. Baltimore MD: Johns Hopkins University Press.

Wallman, Katherine (1998). "Data on Race and Ethnicity: Revising the Federal Standard." American Statistician 52(1): 31-33.

Washington Postet al. (2001). Race and Ethnicity in 2001: Attitudes, Perceptions, and Experiences. Menlo Park CA: Kaiser Family Foundation http://www.kff.org/kaiserpolls/3143-index.cfm

washingtonpost.com/wp-srv/nation/sidebars/polls/race071101.htm

http://www.kff.org/kaiserpolls/loader.cfm?url=/commonspot/security/getfile.cfm\&PageID=1383 9.

Waterston, Adriana (2004). The Dawning of Multicultural America. Larchmont NY: Horowitz Associates Inc. Market Research \& Consulting, www.horowitzassociates.com/dawning.pdf.

Williams, Diana (2006). Family Drama: The Political Economy of Interracial Inheritance in Nineteenth Century Louisiana. Cambridge MA: Harvard University, Program in the History of American Civilization, ww.dianairenewilliams.com.

Williams, Kim (2006). Mark One or More: Civil Rights in Multiracial America. Ann Arbor MI: University of Michigan Press. 
Wilson, James Q. (1989). Bureaucracy: What Government Agencies Do and Why They Do It. New York: Basic Books.

Yen, Hope (2009). Multiracial Americans Become Fastest Growing Us Group. Huffington Post.www,huffingtonpost.com/2009/05/29/.

Zackondik, Teresa. 2001. "Fixing the Color Line: The Mulatto, Southern Courts, and Racial Identity." American Quarterly 53: 420-451.

1 http://www.youtube.com/watch?v=EADUQWKoVek; Migration News 2004

2 (U. S. Bureau of the Census 2001).

3 (Vasconcelos 1979 [1925]).

${ }^{4} \mathrm{~A}$ few words on terminology: we use mixed race, multiracial(ism), biracial, and racial mixture interchangeably. We specify at appropriate locations whether Hispanics or Latinos are a "race" for purposes of the analysis. Except where specified, we do not treat people of mixed nationalities (Japanese-Korean; Swedish-Armenian) as multiracial.

By "recognition," we mean that an external actor or agency (e.g. employer, census) permits individuals to describe themselves as multiracial or to choose more than one race. "Selfdefinition" or "identification," means that an individual chooses his or her own racial label. By "identity," we mean that the person sees his or her racial self-definition to be an important constitutive part of who he or she really is, with political, emotional, behavioral, or cultural implications.

We define a society's racial order as the widely understood and accepted system of beliefs, laws, and practices that organize relationships among groups defined as races or ethnicities (Powell 2009).

${ }^{5}$ Gans 2007, 271-72.

${ }^{6}$ Quoted in (Williams, K. 2006), 42.

7 For a similar argument see Rockquemore et al. 2009.

8 (Sidanius et al. 2001); (Telles 2004); (Morning 2006).

9 (Marx 1998); (King and Smith 2005); (Sawyer 2005); (Smith 2007) and the books therein. ${ }^{10}$ (Hancock 2007).

11 (Shelby 2005); (Joseph 2007); (Hollinger 2006); (Rodriguez 2007); (Valle and Torres 2000).

${ }^{12}$ A very small sample includes (Jacobson 1998; Roediger 2005); (Hattam 2007); (Hochschild and Powell 2008); (Novkov 2008); (Gross 2008); (Pascoe 2009).

${ }^{13}$ Quotations in this paragraph are from, in order, (Mettler and Soss 2004), 61; (Igo 2007), 4; and (Anderson 2002), 38. See also (Foucault 1979); (Scott 1998).

${ }^{14}$ (Siegel and Passel 1979).

${ }^{15}$ Quoted in (Schor 2005), 99-100.

16 (Skerry 2000); (Skrentny 2002).

17 (Office of Management and Budget 1977); (Office of Management and Budget 1997).

18 (Montejano 1987); (Skrentny 2002); (Haney Lopez 2003).

${ }^{19}$ Hispanic remains an ethnicity rather than becoming a race on the census because tests have shown that more people define themselves as Hispanic or Latino when it remains a separate question, prior to the race question, than when it is added to the list of federally-approved races on official data collection forms.

${ }^{20}$ (U. S. Bureau of the Census 2002), 27. No instruction explained how to determine fractions of black blood. 
${ }^{21}$ (Nobles 2000); (Hochschild and Powell 2008).

22 The census office understood that these boundaries among groups were hopelessly blurred. As the 1895 Report on Population put it,

The persons of negro descent are further classified under the law, as follows: negroes, 6,337,980; mulattoes, 956,989; quadroons, 105,135, and octoroons, 69,936. These figures are of little value. Indeed, as an indication of the extent to which the races have mingled, they are misleading (U. S. Census Office 1895), xciii.

23 (Stephenson 1910): 14).

24 (Murray 1997 [1950]); (Hollinger 2003); (Williams, D. 2006); (Novkov 2008).

${ }^{25}$ We base this claim on our analysis of Murray 1997[1950]. Before 1920, most state laws defined as Negro all people with one Black grandparent (that is, having $1 / 4$ Negro "blood"). After 1920, most state laws about marriage, segregation, and property ownership broadened the definition of Black to include people with "any appreciable amount of Negro blood" or as having 1/8th or 1/16th Black ancestry. Some variation persisted across states; as David Hollinger notes, "hypodescent... was not universally applied in all states even after 1924. Louisiana law, for example, was always more responsive to degrees of African descent than the laws of most other states." He provides a citation to Zackondik 2001 (Hollinger 2003: footnote 29).

${ }^{26}$ (Hochschild et al. 2008).

${ }^{27}$ For this history, see (Jones 2000); (DaCosta 2004); (Williams, K. 2006).

${ }^{28}$ NAS reports included (Edmonston and Schultze 1995) and (Edmonston et al. 1996) Experts included (Smith and Edmonston 1997); (Hirschman et al. 1999); and (Goldstein and Morning 2000). (Wallman 1998) gives the government analysis, and (Williams, K. 2006) analyses state activity.

29 (Office of Management and Budget 1997).

${ }^{30}$ Some multiracial proponents were disappointed that OMB gave respondents the option to choose one or more races, rather than establishing a stand-alone category of "multiracial." In the eyes of its proponents, "multiracial" would have signaled a distinct group identity, whereas "mark one or more" permits individual or governmental analysts to reallocate mixed race individuals back into their specific races.

31 (Prewitt 2001), 40. Prewitt implemented the decision, but did not hold the position of census director when OMB issued its 1997 Revisions.

32 Both comments are quoted in (Chandler and Glod 2009)

${ }^{33}$ Unless noted, all quotations in this and the next paragraph are from the Federal Register.

34 (U. S. Equal Employment Opportunity Commission 2005), 71295; (U. S. Department of Education 2007); Ibid., p. 59267. Education Week described this "Guidance" as "holding firm in the face of objections" http://www.edweek.org/ew/articles/2007/10/23/09raceregs_web.h27.html? (accessed 2/17/08). Hinting at some, the Association for Institutional Research noted that the new standards "may require institutions to make considerable investments of both time and money," ranging from computer programming to analyses of any statistically-induced rise in Latino and decline in African American enrollment (Broh and Minicucci 2008). AIR also observed, more favorably, that "the new federal rules... will increase what many institutions know about the diversity of their community by capturing information on the increasing number of people who identify with more than one race" http://www.airweb.org/page.asp?page=1393 (accessed 2/17/08).

${ }^{35}$ Communication with authors, January 2008. 
36 (Broh and Minicucci 2008).

37 (U. S. Equal Employment Opportunity Commission 2005), 71296.

${ }^{38}$ On intermarriage, see (Farley 2007); (Qian and Lichter 2007).

An analysis of pooled 1997-2001 data from the National Health Interview Survey (NHIS) does include Hispanics as a "racial" group. It finds that among married women, 97 percent of Whites, 96 percent of Blacks, 74 percent of Asians, 46 percent of American Indians, and 82 percent of Hispanics are in homogamous marriages. Among married men, the percentages are, respectively, 97, 87, 88, 41, and 83. Thus Hispanics' intermarriage rate is roughly comparable to that of Asian Americans (Bratter and Eschbach 2006).

39 The decline in Asian intermarriage does not hold for native-born persons http://www.economics.harvard.edu/faculty/fryer/files/interracial_marriage_onlineappendix_figs. pdf): figure 1). These data exclude Hispanics, but a separate analysis found that about 14 percent of married Hispanics have non-Hispanic spouses. Intermarriage is much higher among native-borns than among immigrants (Lee and Edmonston 2006). These estimates are conservative, since the data do not take into account the third generation "loss" of Hispanics into White-only identity, or the higher intermarriage rate of "some other race" identifiers, who are disproportionately Hispanic.

40 (Fryer Jr. 2007).

41 (New American Media 2007a).

42 (Kasinitz et al. 2008).

43 (New American Media 2007b). The survey excluded Whites.

${ }^{44}$ On children, see (Farley 2007). On unmarried partners, see (Simmons and O'Connell 2003). On California, see (Tafoya 2000).

${ }^{45}$ Goldstein communication with the authors, January 29, 2009.

${ }^{46}$ (Hochschild et al. 2008).

${ }^{47}$ Chicago Defender, Jan. 22, 1949, p.7.

48 (Myrdal 1944).

${ }^{49}$ Gallup 2007.

50 The Gallup Poll is in (Gallup 2007). Endorsement of intermarriage is in (Pew Research Center for the People and the Press 1999). Exaggeration is in (Gallup/ CNN/ U.S.A. Today 2001).

${ }^{51}$ (Stanfield 1999).

52 (Waterston 2004), emphasis in original.

53 (Wilson 1989); (Shklar 1991); (Mettler 2002); (Schuck 2009).

${ }_{55}^{54}$ (Farley 2004), 123, 147.

55 Direct comparisons between census 2000 and later ACS's are inappropriate because imputation rules for allocating respondents into racial categories differ across years. In addition, the sampling frame and procedures for the ACS have only recently been stabilized, and some demographers doubt the comparability to the census of even recent data. The census bureau's Annual Population Estimates differ from the ACS because of different imputation rules as well as different strategies for calculating groups' sizes. The Estimates take into account births, deaths, and net migration, but not self-reports in the years after the census; they therefore do not incorporate any changes in people's propensity to identify with multiple races, as the ACS can do. Finally, the NHIS differs from both census bureau measures, presumably because of sampling strategies, question wording and placement, and other house effects. 
For the 2000 census itself, it may be appropriate to drop respondents who chose Some Other Race (SOR) + one of the standard races from the category of multiracial, on the grounds that many chose White and wrote in Hispanic or an equivalent term - that is, they are White Hispanics rather than being of mixed race as that term is commonly used. Deleting SORs from the 2000 census leaves a self-identified multiracial population for that year of 1.4 percent.

${ }^{56}$ The proportions choosing another race + either Asian, White, Native Hawaiian or Other Pacific Islander (NHOPI), or Hispanic all remained stable or declined slightly from census 2000 to the 2007 ACS.

${ }^{57} \mathrm{http}$ ://factfinder.census.gov: table S0201.

58 (Lee 2004), 15; (Newsweek 2009).

${ }^{59}$ For first year students, see (Massey et al. 2003); for selective colleges, see (Broh and Minicucci 2008), 16.

60 Authors' analysis of (Portes and Rumbaut 1991-2006).

61 (Espiritu 1992); (Haney-López 2003); (Lien et al. 2004); (Aoki and Takeda 2009); (Garcia Bedolla 2009).

62 (Norton 1997), 260; (McDougall 1997), 308.

${ }^{63}$ Add article by author after review.

64 ("Why the Census is Important to You" 2000).

65 (U. S. Equal Employment Opportunity Commission 2005), 71296; (Department of Education 2007), 59271.

${ }^{66}$ (St. James 2007).

${ }^{67}$ (Williams, K. 2006).

68 (Campbell 2003).

69 (Dawson 1994); (Chong and Rogers 2004); (Hutchings et al. 2005); (Lien et al. 2003).

${ }^{70} \mathrm{http}$ : www.mavinfoundation.org/index.html

${ }^{71} \mathrm{http}: / / \mathrm{www} \cdot d \mathrm{mmariaroot} . c o m /$ doc/BillOfRights.pdf

72 Authors' analysis of Survey by Newsweek and Princeton Survey Research Associates 1995. Since usually more than half of African Americans express a sense of linked fate and racial consciousness when asked, at least some of the Black endorsers of multiracialism in the Newsweek survey are presumably also strongly racially identified.

${ }^{73}$ UC groups are in (Andrews and Chun 2007), 89; MAVIN mission statement is at http://www.mavinfoundation.org/about/mission.html; MALDEF is quoted in (Williams, K. 2006), 42.

74 (Shih et al. 2007); (Bonam \& Shih 2009).

75 (Quillian and Redd 2009); (Shih, et al. 2007).

${ }^{76}$ Authors' analysis of (Newsweek 1995b).

${ }^{77}$ Authors' analysis of (Portes and Rumbaut 1991-2006).

78 Authors' analysis of (Newsweek 1995a); (Pew Research Center for the People and the Press 2007).

${ }^{79}$ (Newsweek 1995b).

80 (Washington Post et al. 2001). See also (Matsuoka 2008).

${ }^{81}$ Those who identified as Black + some other race, however, held views on this question similar to the views of Black monoracials. Analysis for the authors by HERI staff of (Cooperative Institutional Research Program various).

${ }^{82}$ Authors analysis of (Massey and Charles 2006). 
${ }^{83}$ The only exceptions to multiracials' intermediate position come in measures that revolve around mixture, such as support for interracial dating, and counting multiracials on the Census. Not surprisingly, more multiracials supported these measures than did their monoracial peers. ${ }_{85}^{84}$ Quoted in (Yen 2009).

${ }^{85}$ Starting in 2004, the ACS sample includes about 3 million households annually. NHIS samples range from a) for persons, 100,760 in 2001 to 74,236 in 2008; b) for a separate adult sample, 33,326 in 2001 to 21,781 in 2008, and 3) for a separate child sample, 13,579 in 2001 to 8,815 in 2008. 